\title{
Regioselective (Biomimetic) Synthesis of a Pentasulfane From Ortho-benzoquinone
}

David Aebisher, Edyta M. Brzostowska, Adaickapillai

Mahendran, and Alexander Greer

Department of Chemistry, Graduate Center \& The City University of New York (CUNY), Brooklyn College, Brooklyn, New York 11210.E-mail: agreer@brooklyn.cuny.edu

\section{Supporting Information}

\section{Table of Contents}

\section{Page}

S1-3 Table of Contents.

S4-6 Experimental Procedures

S7 Figure 1: GC/MS trace of $\mathrm{H}_{2} \mathrm{~S}_{\mathrm{x}}+o$-benzoquinone crude reaction mixture.

S8 Figure 2: GC/MS trace of $\mathrm{H}_{2} \mathrm{~S}_{\mathrm{x}}+o$-benzoquinone acetylated reaction mixture.

S9 Figure 3: Mass spectrum for acetic acid 2-acetoxy-5,6,7,8,9-pentathiabenzocyclohepten-1-yl ester or "diacetylated 4."

S10 Figure 4: ${ }^{1} \mathrm{H}$ NMR of acetic acid 2-acetoxy-5,6,7,8,9-pentathiabenzocyclohepten-1-yl ester or "diacetylated 4" in $\mathrm{CDCl}_{3}$.

S11 Figure 5: ${ }^{1} \mathrm{H}$ NMR of acetic acid 2-acetoxy-5,6,7,8,9-pentathiabenzocyclohepten-1-yl ester or "diacetylated 4" in $\mathrm{CDCl}_{3}$ expanded to show aromatic protons.

S12 Figure 6: ${ }^{1} \mathrm{H}$ NMR of acetic acid 2-acetoxy-5,6,7,8,9-pentathiabenzocyclohepten-1-yl ester or "diacetylated 4" in $\mathrm{CDCl}_{3}$ expanded to show acetyl protons.

S13 Figure 7: ${ }^{1} \mathrm{H}$ NMR of acetic acid 2-acetoxy-5,6,7,8,9-pentathiabenzocyclohepten-1-yl ester or "diacetylated 4" in $\mathrm{C}_{6} \mathrm{D}_{6}$. 
S14 Figure 8: ${ }^{13} \mathrm{C}$ NMR of acetic acid 2-acetoxy-5,6,7,8,9-pentathiabenzocyclohepten-1-yl ester or "diacetylated 4" in $\mathrm{CDCl}_{3}$.

S15 Figure 9: ${ }^{1} \mathrm{H}$ NMR of 3-mercaptocatechol, 5, in acetone- $d_{6}$.

S16 Figure 10: ${ }^{1} \mathrm{H}$ NMR of acetic acid 2-acetoxy-3-acetylsulfanyl-phenyl ester or "triacetylated $\mathbf{5}$ " in acetone- $d_{6}$.

S17 Figure 11: ${ }^{13} \mathrm{C}$ NMR of acetic acid 2-acetoxy-3-acetylsulfanyl-phenyl ester or "triacetylated $\mathbf{5}$ " in acetone- $d_{6}$.

S18 Figure 12: HRMS of acetic acid 2-acetoxy-3-acetylsulfanyl-phenyl ester or "triacetylated 5."

S19 Figure 13: ${ }^{1} \mathrm{H}$ NMR of 4-mercaptocatechol, 6 , in acetone- $d_{6}$.

S20 Figure 14: ${ }^{1} \mathrm{H}$ NMR of acetic acid 2-acetoxy-4-acetylsulfanyl-phenyl ester or "triacetylated 6 " in acetone- $d_{6}$.

S21 Figure 15: ${ }^{13} \mathrm{C}$ NMR of acetic acid 2-acetoxy-4-acetylsulfanyl-phenyl ester or "triacetylated 6" in acetone- $d_{6}$.

S22 Figure 16: Mass spectrum of acetic acid 2-acetoxy-3-acetylsulfanyl-phenyl ester or "triacetylated 6."

S23 Figure 17: HRMS of acetic acid 2-acetoxy-3-acetylsulfanyl-phenyl ester or "triacetylated 6."

S24 Figure 18: ${ }^{1} \mathrm{H}$ NMR of acetic acid 2-acetoxy-6-(2,3-diacetoxy-phenylsulfanyl)phenyl ester or "tetraacetylated 7" in $\mathrm{CDCl}_{3}$.

S25 Figure 19: Mass spectrum of acetic acid 2-acetoxy-6-(2,3-diacetoxyphenylsulfanyl)-phenyl ester or "tetraacetylated 7."

S26 Figure 20: ${ }^{1} \mathrm{H}$ NMR of acetic acid 2-acetoxy-3-(2,3-diacetoxyphenyldisulfanyl)-phenyl ester or "tetraacetylated 8 " in acetone- $d_{6}$.

S27 Figure 21: ${ }^{13} \mathrm{C}$ NMR of acetic acid 2-acetoxy-3-(2,3-diacetoxyphenyldisulfanyl)-phenyl ester or "tetraacetylated 8 " in acetone- $d_{6}$.

S28 Figure 22: Mass spectrum of acetic acid 2-acetoxy-3-(2,3-diacetoxyphenyldisulfanyl)-phenyl ester or "tetraacetylated 8."

S29 Figure 23: HRMS of acetic acid 2-acetoxy-3-(2,3-diacetoxy-phenyldisulfanyl)phenyl ester or "tetraacetylated 8."

S30 Figure 24: 'H NMR of 3,4-dimercapto-benzene-1,2-diol or "tetraacetylated 9" in acetone- $d_{6}$. 
S31 Figure 25: Mass spectrum of 3,4-dimercapto-benzene-1,2-diol or "tetraacetylated 9."

S32 Figure 26: Mass Spectrum of acetic acid 3,2',3'-triacetoxy-biphenyl-2-yl ester or "tetraacetylated 10."

S33 Figure 27: Mass spectrum of acetic acid 2-(3,4-diacetoxy-phenoxy)-phenyl ester or "triacetylated 11."

S34 Figure 28: Mass spectrum of acetic acid 1-acetoxy-dibenzo[1,4]dioxin-2-yl ester or "diacetylated 12."

S35 Figure 29: ${ }^{1} \mathrm{H}$ NMR of $o$-benzoquinone in acetone- $d_{6}$.

S36 Description of the geometry of the stationary point of $5(x=8)$ (cartesian coordinates) and absolute energy in hartrees.

S37 Description of the geometry of the stationary point of $\mathbf{1 8}$ (cartesian coordinates) and absolute energy in hartrees.

S38 Description of the geometry of the stationary point of $\mathrm{H}_{2} \mathrm{~S}_{3}$ (cartesian coordinates) and absolute energy in hartrees. 


\section{Experimental Procedures}

Reagents and solvents were available commercially [catechol, silver oxide, acetone, acetone- $d_{6}$, sodium sulfide nonahydrate, elemental sulfur $\left(\mathrm{S}_{8}\right)$, trichloroacetic acid, sodium sulfate (anhydrous), sodium periodate, carbon disulfide, TsOH, DMF, $\mathrm{K}_{2} \mathrm{CO}_{3}$, diethyl ether, THF, $\mathrm{CHCl}_{3}, \mathrm{MeOH}, \mathrm{NaHCO}_{3}$, ethyl acetate, acetic anhydride, DMAP, sodium bicarbonate, hydrochloric acid (12 M), sulfuric acid (1 M), thioacetic acid, magnesium sulfate, ethanol, $\mathrm{CHCl}_{3}, \mathrm{CDCl}_{3}, \mathrm{CH}_{3} \mathrm{CN}$, and hexane] and used as received without further purification. Purification of product mixtures were carried out using silica gel 60F 254 TLC-plates and an HPLC instrument equipped with a C18 column. Proton NMR data acquired at $400 \mathrm{MHz}$ and ${ }^{13} \mathrm{C}$ NMR data acquired at 100.6 MHz. HRMS, UV-visible, IR, and GC/MS data were collected. Examination of temperature programs were used in an effort to limit polysulfide decomposition on the GC/MS injection port. ${ }^{1}$ Comparison of integrated peaks of the compounds provided relative percent yields in the ${ }^{1} \mathrm{H}$ NMR studies.

Ortho-benzoquinone was generated by a literature method. ${ }^{2}$ A solution of catechol $(0.1 \mathrm{~g}, 0.9 \mathrm{mmol})$ and $\mathrm{Ag}_{2} \mathrm{O}(0.4 \mathrm{~g}, 1.8 \mathrm{mmol})$ in acetone $(5 \mathrm{~mL})$ was stirred for 10 min. $\mathrm{Ag}_{2} \mathrm{O}$ was removed from the solution by gravity filtration. Silver is also presumably filtered out of the acetone solution since we do not see the formation of a silver mirror. In some cases, $o$-benzoquinone was generated by a different literature method, ${ }^{3}$ where two solutions were stirred together $[3 \mathrm{~g}(27 \mathrm{mmol})$ catechol in $150 \mathrm{~mL}$ water and 1.1 equivalents $(6.2 \mathrm{~g}, 29 \mathrm{mmol})$ of $\mathrm{NaIO}_{4}$ in $100 \mathrm{~mL}$ of water] and cooled to $0^{\circ} \mathrm{C}$ in an ice bath. $o$-Benzoquinone is stable for 3-4 hours according to ${ }^{1} \mathrm{H} \mathrm{NMR}$, therefore, it is used immediately after preparation. Inorganic polysulfanes $\mathrm{H}_{2} \mathrm{~S}_{\mathrm{x}}$ were 
prepared by the modified method of Steudel. ${ }^{4}$ Two grams of sodium sulfide nonahydrate was dissolved in $2 \mathrm{~mL}$ of water with $1 \mathrm{~g}$ of $\mathrm{S}_{8}$ and heated to $100{ }^{\circ} \mathrm{C}$ over night. To the solution of polysulfanes $\left[\mathrm{NaS}(\mathrm{S})_{x} \mathrm{SNa}\right]$ was added an aqueous solution of $\mathrm{Cl}_{3} \mathrm{CCO}_{2} \mathrm{H}(4 \mathrm{~g}$ in $3 \mathrm{~mL}$ of $\mathrm{H}_{2} \mathrm{O}, 8 \mathrm{mM}$ ), which was stirred at $0{ }^{\circ} \mathrm{C}$. Since the first dissociation constants $\left(\mathrm{p} K_{1}\right)$ of $\mathrm{H}_{2} \mathrm{~S}_{\mathrm{x}}$ molecules in water at $20{ }^{\circ} \mathrm{C}$ range from 7.0 to $3.5,{ }^{5} \mathrm{H}_{2} \mathrm{~S}_{\mathrm{x}}$ precipitated as a yellow oil and was separated from the aqueous phase, and then dissolved in $1 \mathrm{~mL}$ of $\mathrm{CS}_{2}$. With stirring, the $\mathrm{CS}_{2}$ solution of $\mathrm{H}_{2} \mathrm{~S}_{\mathrm{x}}$ was added drop wise to the acetone solution containing $180 \mathrm{mM}$ quinone, where the precipitation of elemental sulfur took place. Elemental sulfur $\left(\mathrm{S}_{8}\right)$ and other insoluble material were removed by gravity filtration. Acetone and $\mathrm{CS}_{2}$ were also then removed by rotary evaporation leaving a light brown viscous liquid.

The acetylation reaction. The quinone $-\mathrm{H}_{2} \mathrm{~S}_{\mathrm{x}}$ product mixture was dissolved in $3.6 \mathrm{~mL}$ ethyl acetate, followed by addition of $0.2 \mathrm{eq}(0.006 \mathrm{~g}, 0.18 \mathrm{mmol})$ DMAP and (230 $\mu \mathrm{L}, 2.52 \mathrm{mmol})$ acetic anhydride. After stirring for $16 \mathrm{~h}$, the mixture was diluted with $5 \mathrm{~mL}$ ethyl acetate, washed twice with $10 \mathrm{~mL}$ saturated $\mathrm{NaHCO}_{3}$ and brine, dried with anhydrous $\mathrm{Na}_{2} \mathrm{SO}_{4}$, and then separated by preparative HPLC and/or preparative TLC.

The reaction of quinone with thioacetic acid was conducted via two different methods depending on the regioselectivity desired. Method 1: With stirring $3 \mathrm{~g}$ (27 mmol) catechol was dissolved in $150 \mathrm{~mL}$ water and the solution cooled in an ice bath. To this solution was added 1.1 equivalents $(6.2 \mathrm{~g}, 29 \mathrm{mmol})$ of $\mathrm{NaIO}_{4}$ in $100 \mathrm{~mL}$ of water. The dark red aqueous solution containing the $o$-benzoquinone was then extracted twice with $\mathrm{CH}_{2} \mathrm{Cl}_{2}$. Thioacetic acid ( $\left.2 \mathrm{~mL}, 28 \mathrm{mmol}\right)$ was dissolved in $100 \mathrm{~mL}$ of $\mathrm{CH}_{2} \mathrm{Cl}_{2}$ and 
added drop wise to $o$-benzoquinone $(18 \mathrm{mmol})$ in $60 \mathrm{~mL}$ of $\mathrm{CH}_{2} \mathrm{Cl}_{2}$ and stirred for an additional 20 minutes. The organic layer is filtered and dried with sodium sulfate and $\mathrm{CH}_{2} \mathrm{Cl}_{2}$ is removed by rotary evaporation. Method 2: Thioacetic acid ( $\left.2 \mathrm{~mL}, 28 \mathrm{mmol}\right)$ was added to $100 \mathrm{~mL} 5 \% \mathrm{NaHCO}_{3}$ solution. Evolution of $\mathrm{CO}_{2}$ was noted, as well as a solution color change from clear to light yellow upon dissolving of the thioacetic acid. The solution containing thioacetic acid was added to $o$-benzoquinone $(18 \mathrm{mmol})$ in 60 $\mathrm{mL}$ acetone and stirred for 20 minutes. The resulting mixture was then acidified with 100 $\mathrm{mL}$ of $4 \mathrm{~N} \mathrm{HCl}$ and extracted with $\mathrm{CH}_{2} \mathrm{Cl}_{2}(3 \times 50 \mathrm{~mL})$. The organic layer was dried with sodium sulfate and $\mathrm{CH}_{2} \mathrm{Cl}_{2}$ was removed by rotary evaporation. Adding of $2 \mathrm{~g}$ of the acetylated sulfur-containing catechols to $60 \mathrm{~mL}$ of $4 \mathrm{~N} \mathrm{NaOH}$, followed by refluxing under Ar for 20 minutes, led to their hydrolysis. The solution was allowed to cool to room temperature and then acidified with $4 \mathrm{~N} \mathrm{HCl}$. Extraction with $\mathrm{CH}_{2} \mathrm{Cl}_{2}(3 \times 25 \mathrm{~mL})$ followed by rotary evaporation yielded a red viscous oil (98\% Yield).

Acetylated 10-12 were generated in a reaction of $o$-benzoquinone $(1.0 \mathrm{~g}, 9.2$ mmol), generated from $\mathrm{Ag}_{2} \mathrm{O}$ with catechol $(1.0 \mathrm{~g}, 9.0 \mathrm{mmol})$ in a solution of $5 \%$ $\mathrm{NaHCO}_{3}$. The reaction was stirred for 20 minutes, and subsequently acidified with 100 $\mathrm{mL}$ of $4 \mathrm{~N} \mathrm{HCl}$. Extractions were conducted with $\mathrm{CH}_{2} \mathrm{Cl}_{2}(3 \times 30 \mathrm{~mL})$, followed by a reaction with pyridine and acetic anhydride.

\section{References}

(1) Block, E. J. Agric. Food Chem. 1993, 41, 692-692.

(2) Harley-Mason J.; Laird A. H. J. Chem. Soc. 1958, 1718-1719.

(3) Chavdarian, C. G.; Castagnoli, N. Jr. J. Med. Chem. 1979, 22, 1317-1322.

(4) Steudel, R. Top. Curr. Chem. 2003, 231, 99-125.

(5) Steudel, R. Ind. Eng. Chem. Res. 1996, 35, 1417-1423. 
Figure 1. GC/MS trace of $\mathrm{H}_{2} \mathrm{~S}_{\mathrm{x}}+o$-benzoquinone crude reaction mixture.

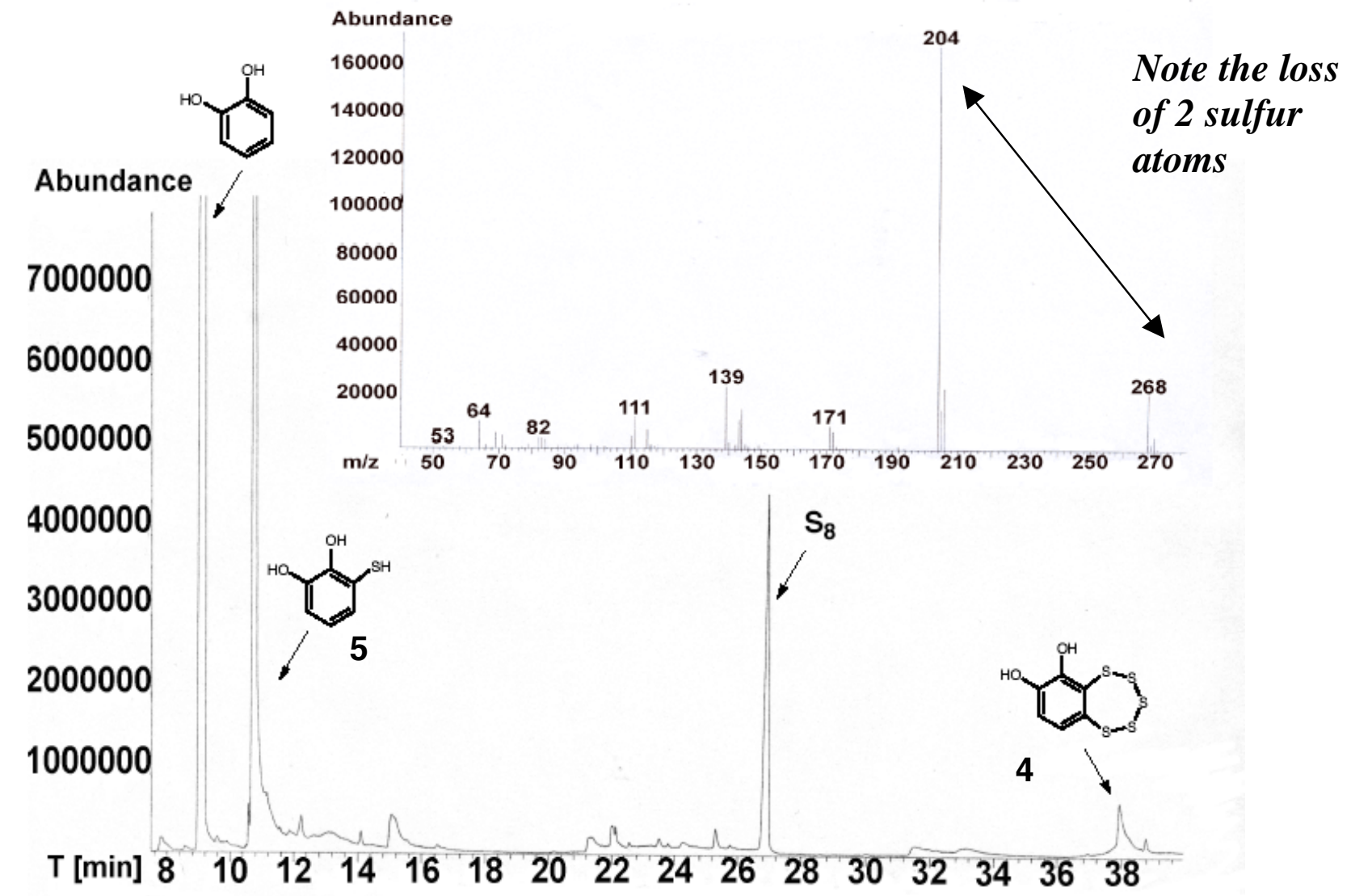


Figure 2. GC/MS trace of $\mathrm{H}_{2} \mathrm{~S}_{\mathrm{x}}+o$-benzoquinone acetylated reaction mixture.

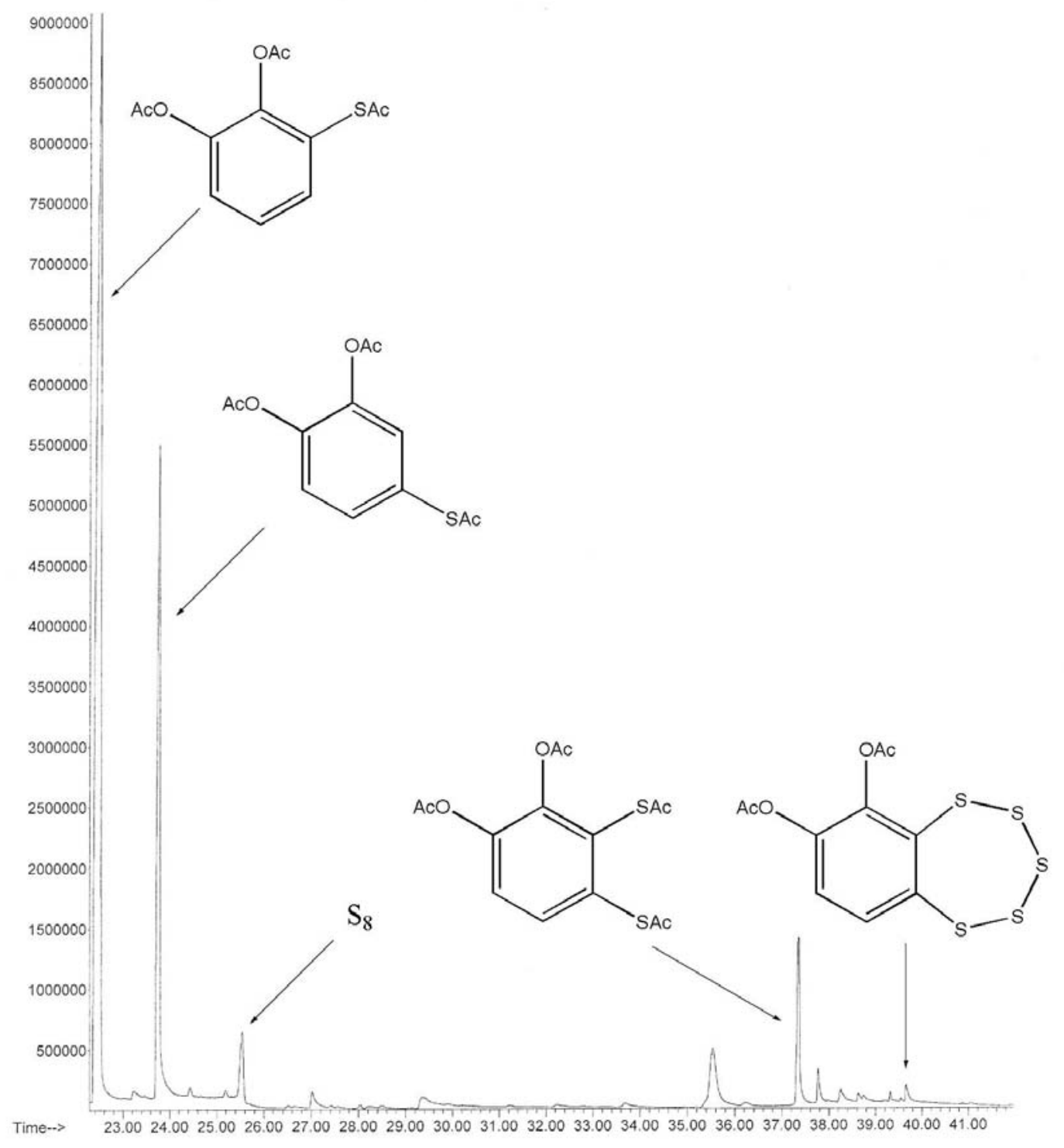


Figure 3. Mass spectrum for Acetic acid 2-acetoxy-5,6,7,8,9-pentathiabenzocyclohepten-1-yl ester or "diacetylated 4."

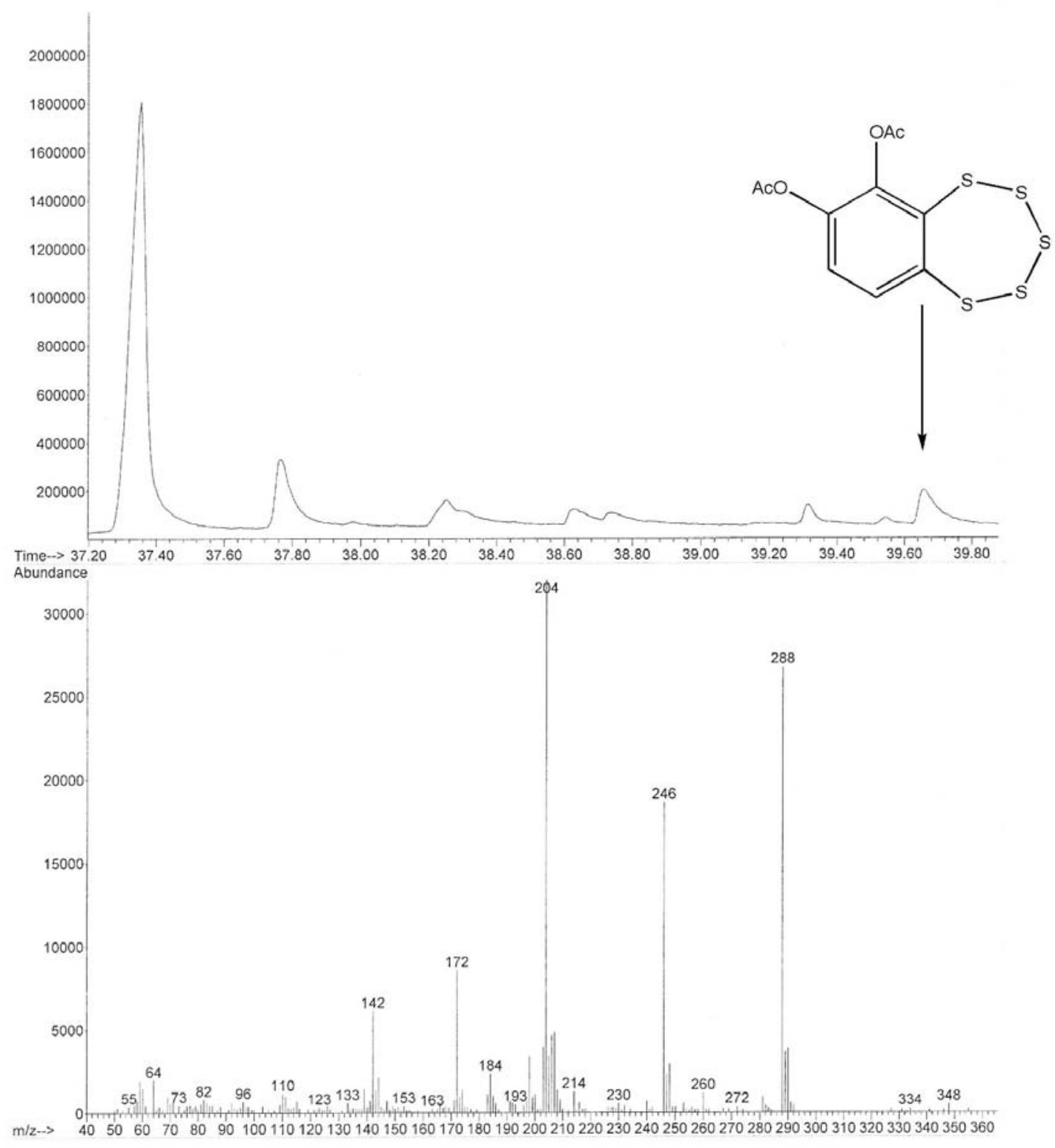


Figure 4. ${ }^{1} \mathrm{H}$ NMR of acetic acid 2-acetoxy-5,6, 7,8,9-pentathiabenzocyclohepten-1-yl ester or "diacetylated 4" in $\mathrm{CDCl}_{3}$.

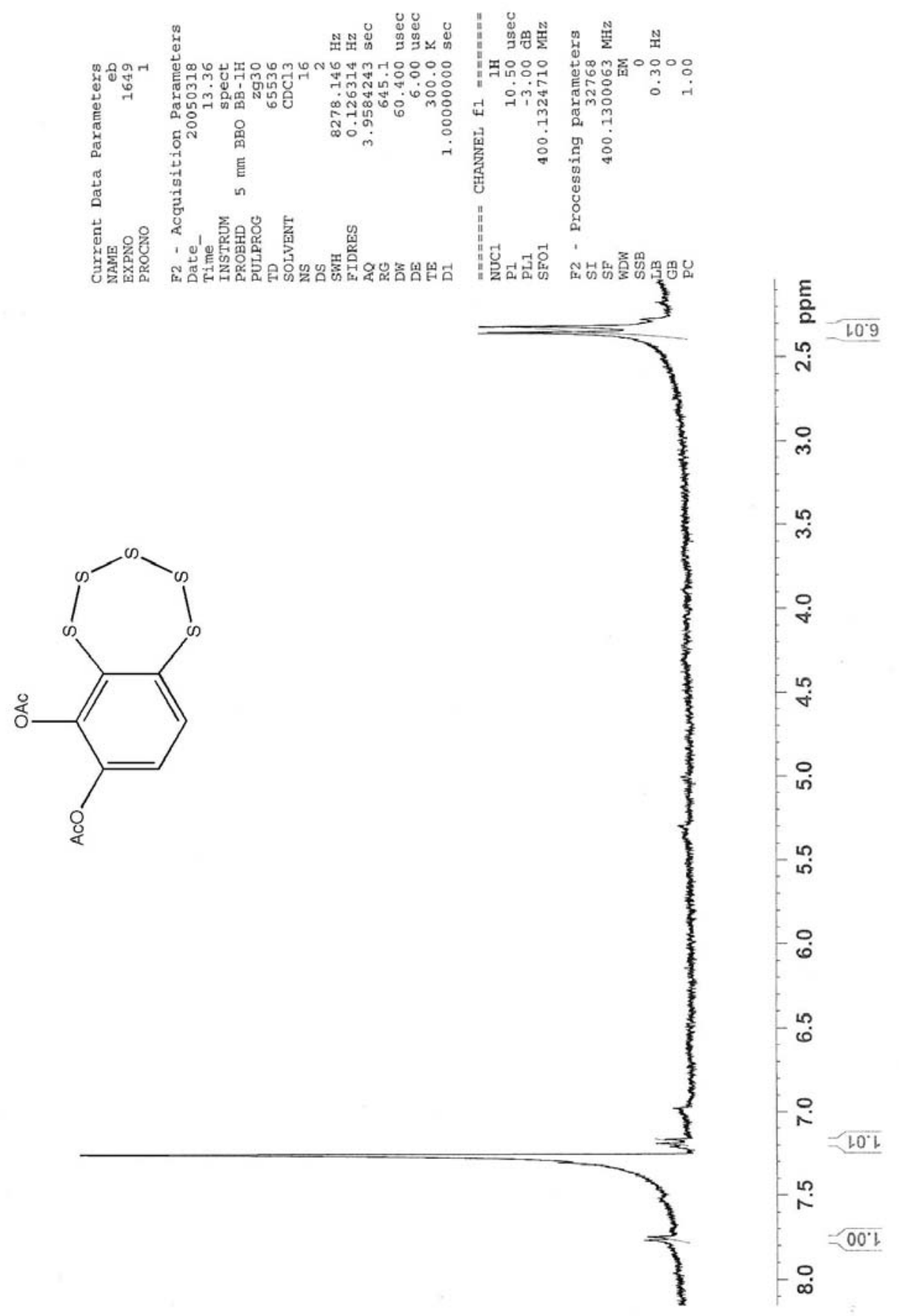


Figure 5. ${ }^{1} \mathrm{H}$ NMR of acetic acid 2-acetoxy-5,6,7,8,9-pentathia-benzocyclohepten1-yl ester or "diacetylated 4" in $\mathrm{CDCl}_{3}$ expanded to show aromatic protons.

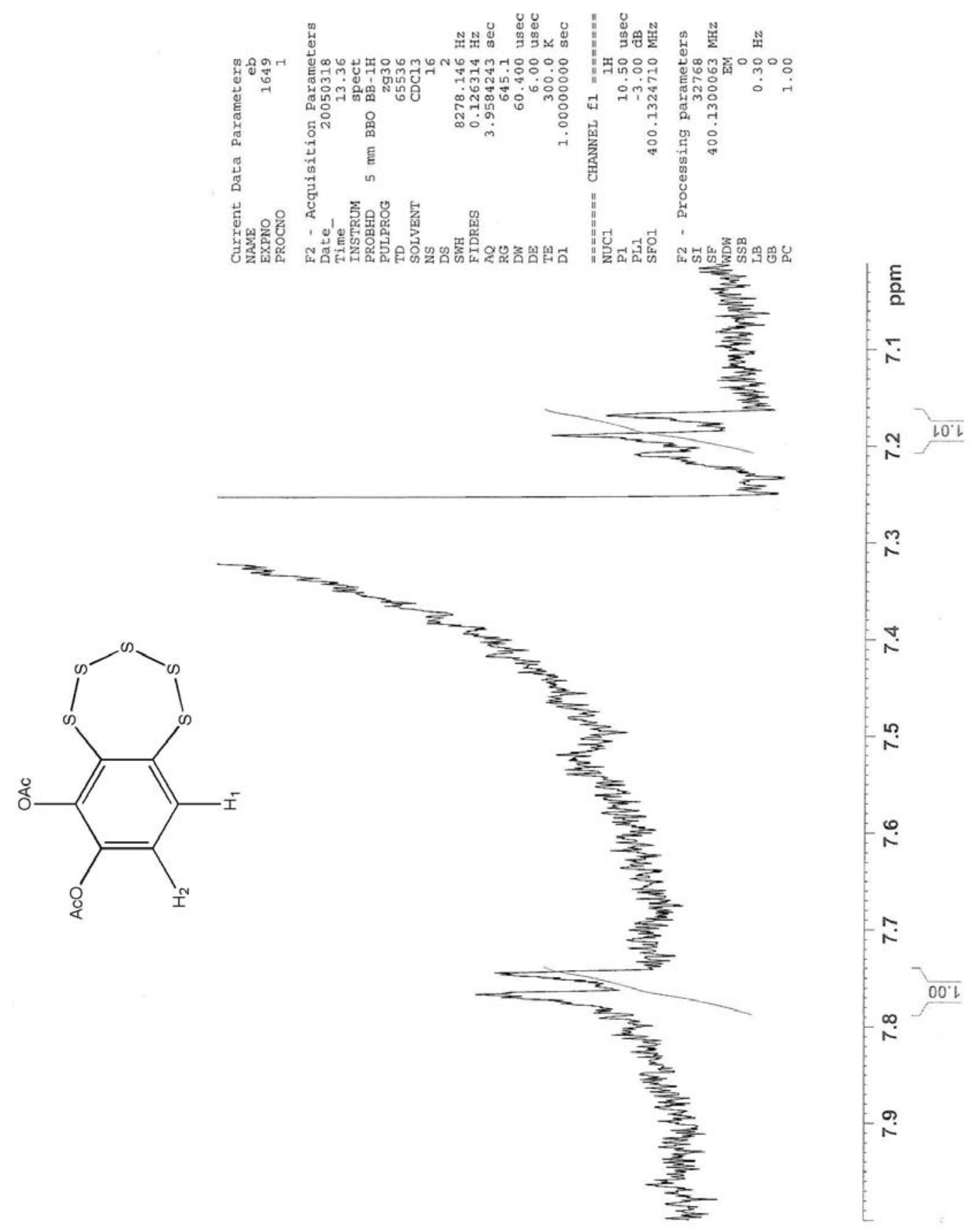


Figure 6. ${ }^{1} \mathrm{H}$ NMR of acetic acid 2-acetoxy-5,6,7,8,9-pentathia-benzocyclohepten1 -yl ester or "diacetylated 4" in $\mathrm{CDCl}_{3}$ expanded to show acetyl protons.

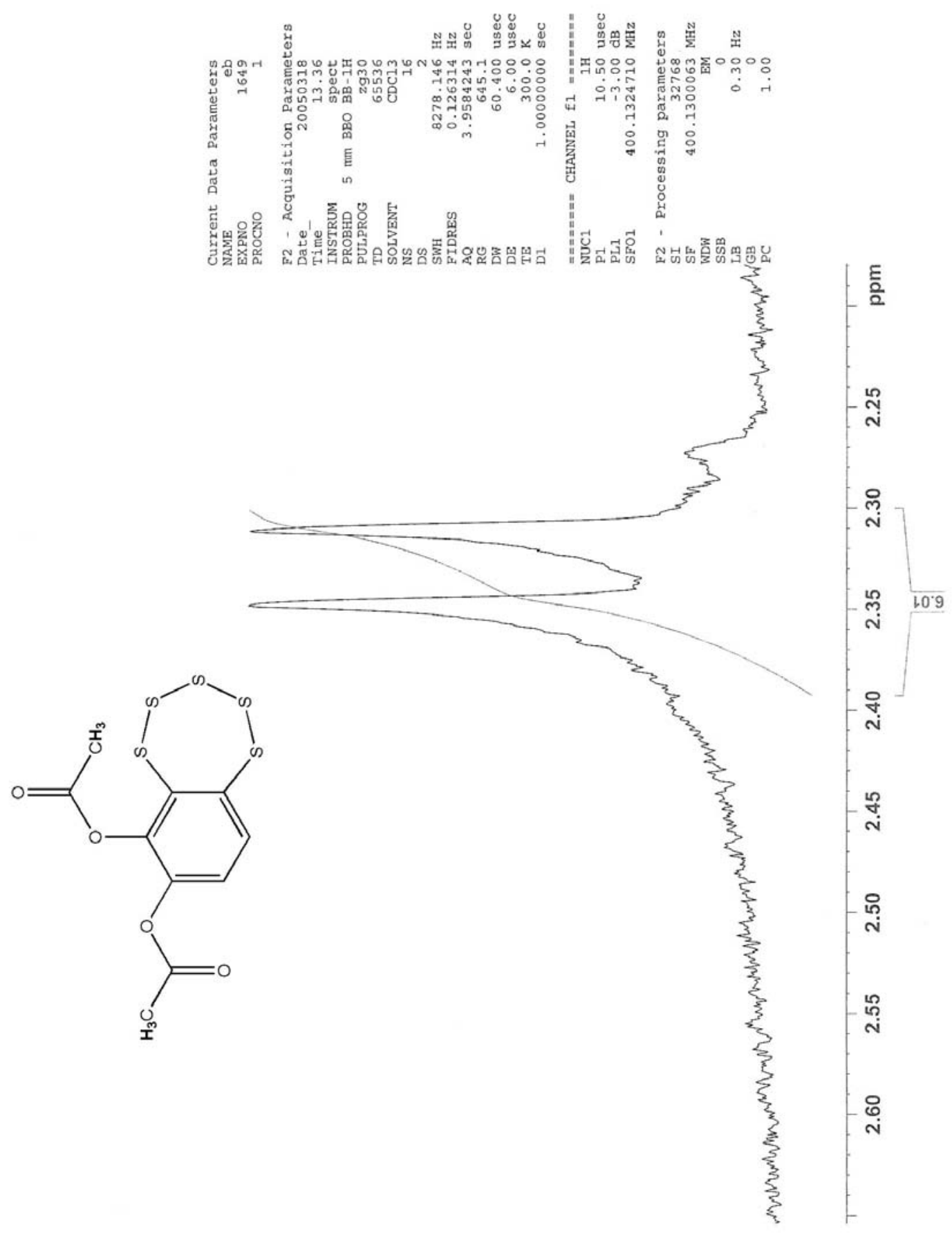


Figure 7. ${ }^{1} \mathrm{H}$ NMR of acetic acid 2-acetoxy-5,6,7,8,9-pentathia-benzocyclohepten-1-yl ester or "diacetylated 4" in $\mathrm{C}_{6} \mathrm{D}_{6}$.
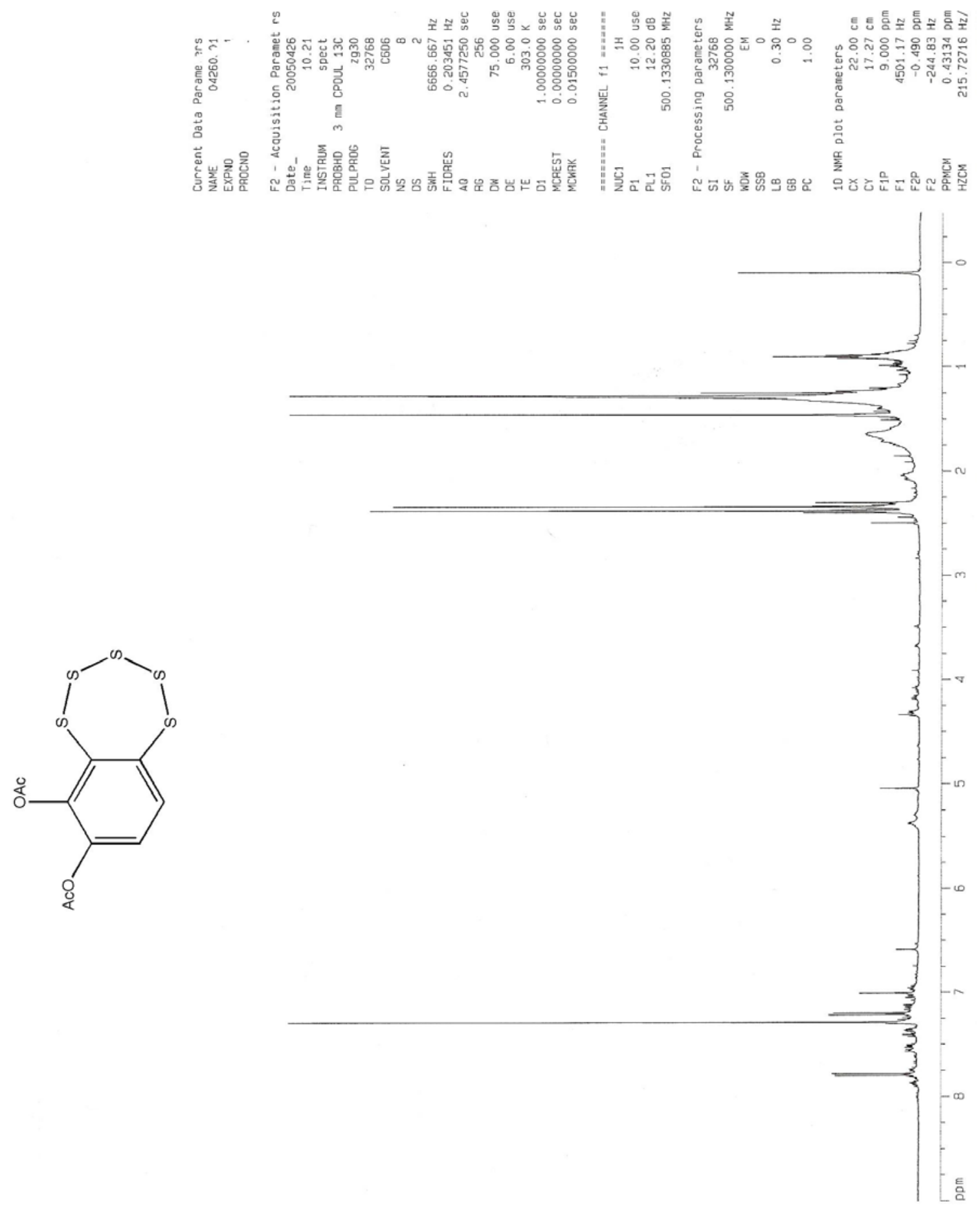
Figure 8. ${ }^{13} \mathrm{C}$ NMR of acetic acid 2-acetoxy-5,6,7,8,9-pentathiabenzocyclohepten-1-yl ester or "diacetylated 4" in $\mathrm{CDCl}_{3}$.

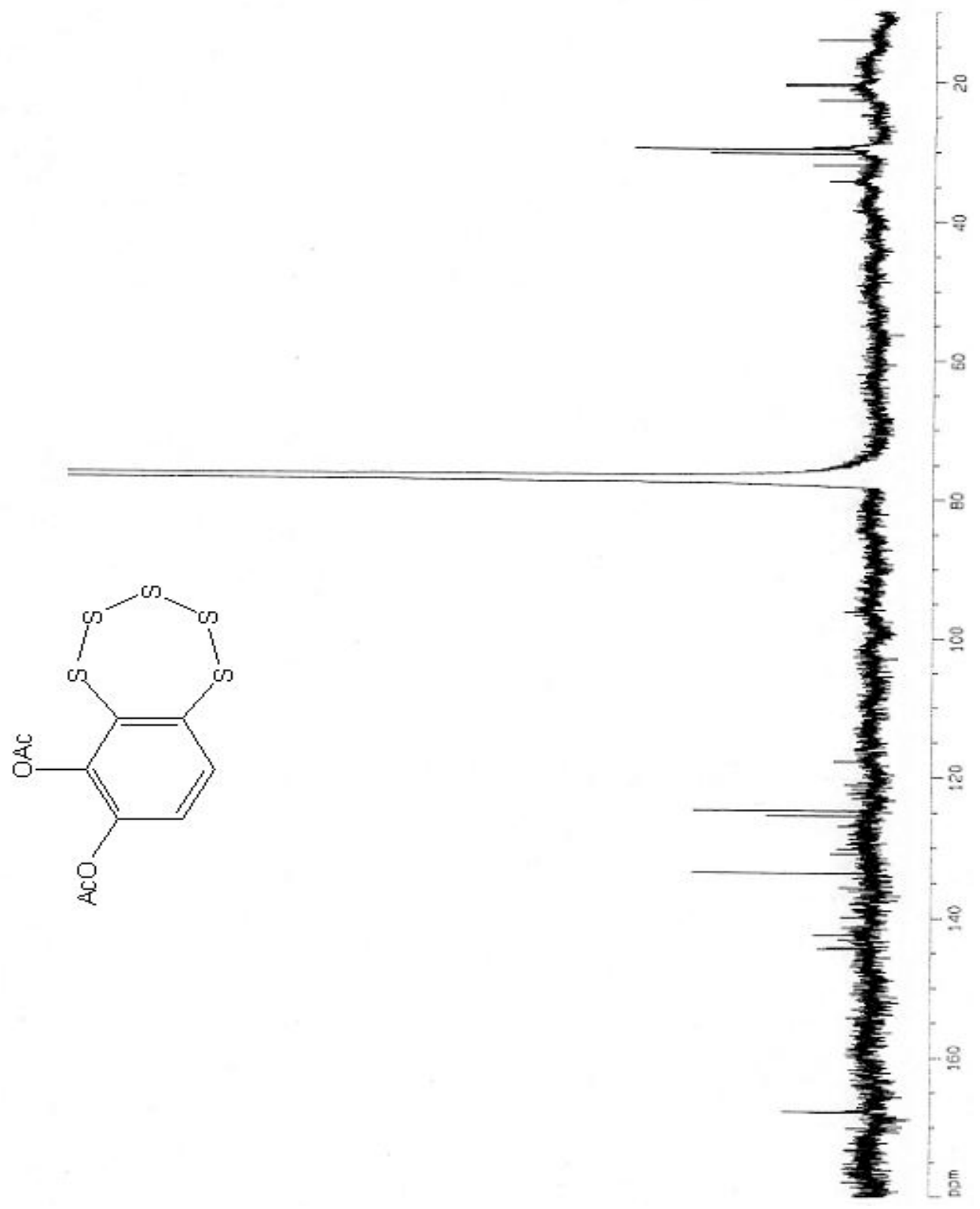


Figure 9. ${ }^{1} \mathrm{H}$ NMR of 3-mercaptocatechol, 5, in acetone- $d_{6}$.

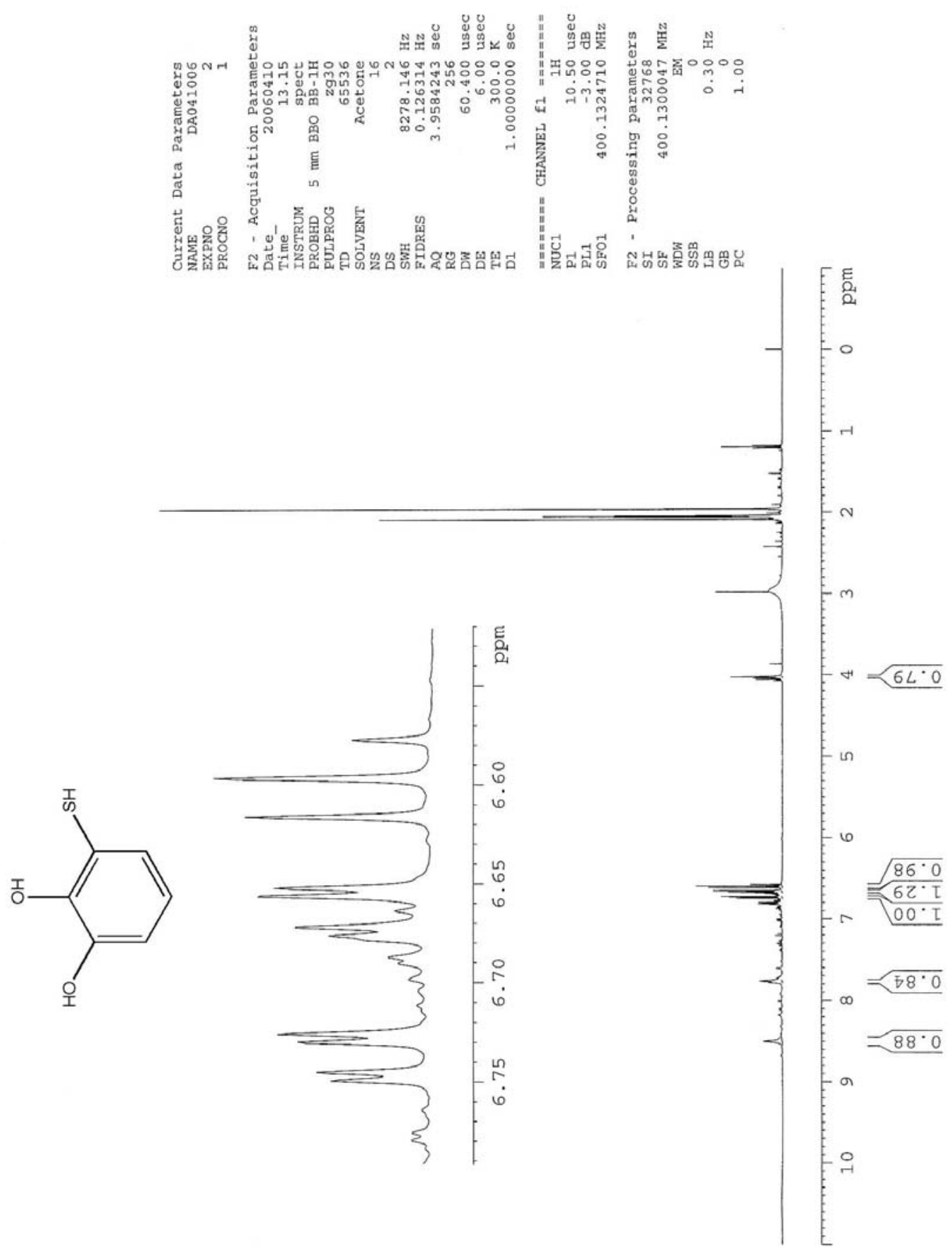


Figure 10. ${ }^{1} \mathrm{H}$ NMR of acetic acid 2-acetoxy-3-acetylsulfanyl-phenyl ester or "triacetylated 5" in acetone- $d_{6}$.

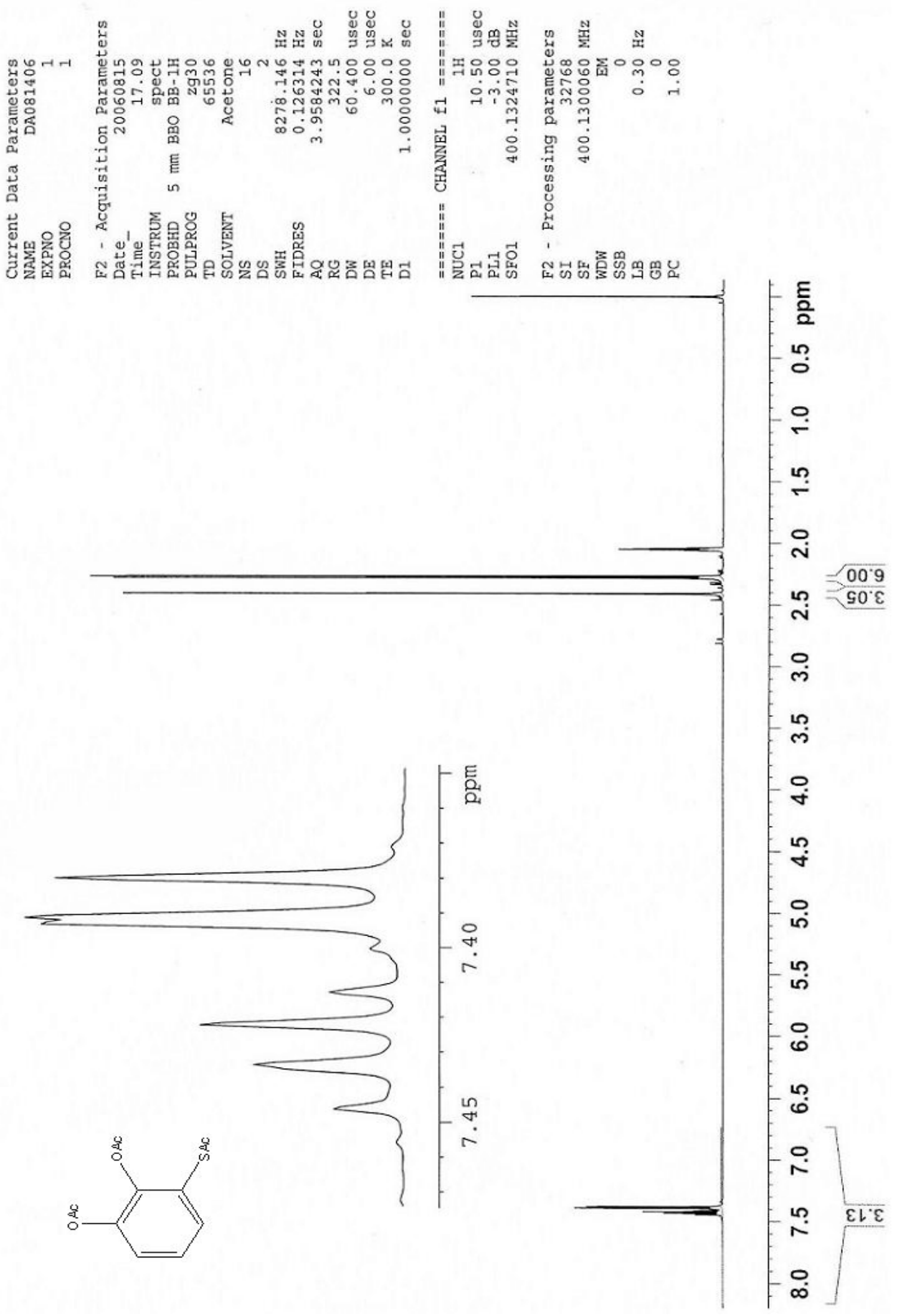


Figure 11. ${ }^{13} \mathrm{C}$ NMR of acetic acid 2-acetoxy-3-acetylsulfanyl-phenyl ester or "triacetylated 5 " in acetone- $d_{6}$.

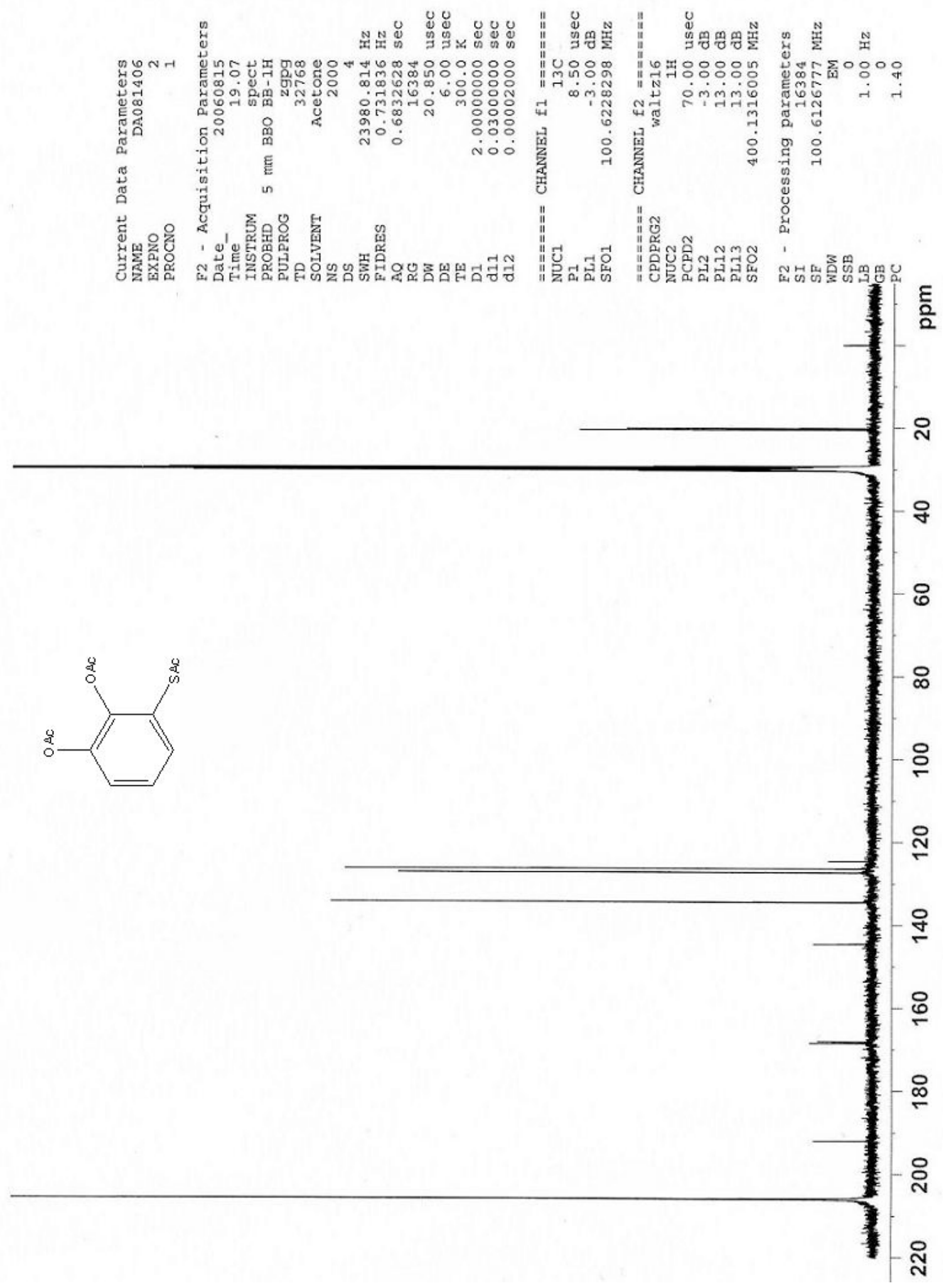


Figure 12. : HRMS of acetic acid 2-acetoxy-3-acetylsulfanyl-phenyl ester or "triacetylated 5."

\section{Empirical Formula Confirmation Report}

Sample Name: 3-mercaptocatechol Sample Location: P1-A1 Sample Id: Operator:

Data File Name: D:IDatal0608281BCAGAG60A.wiff Acq Time: August 28 2006, 01:08:35 PM

Method: D:ITOF_DataldamethodslefcHC4,anmlefc.xm|

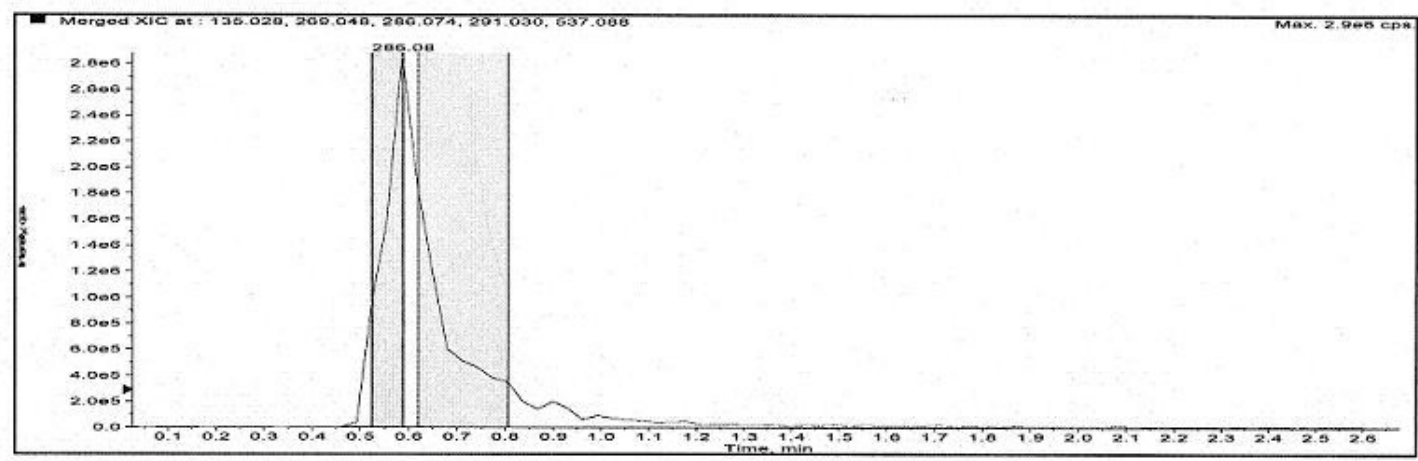

Merged XIC, Period\# : 1 Experiment\# : 1
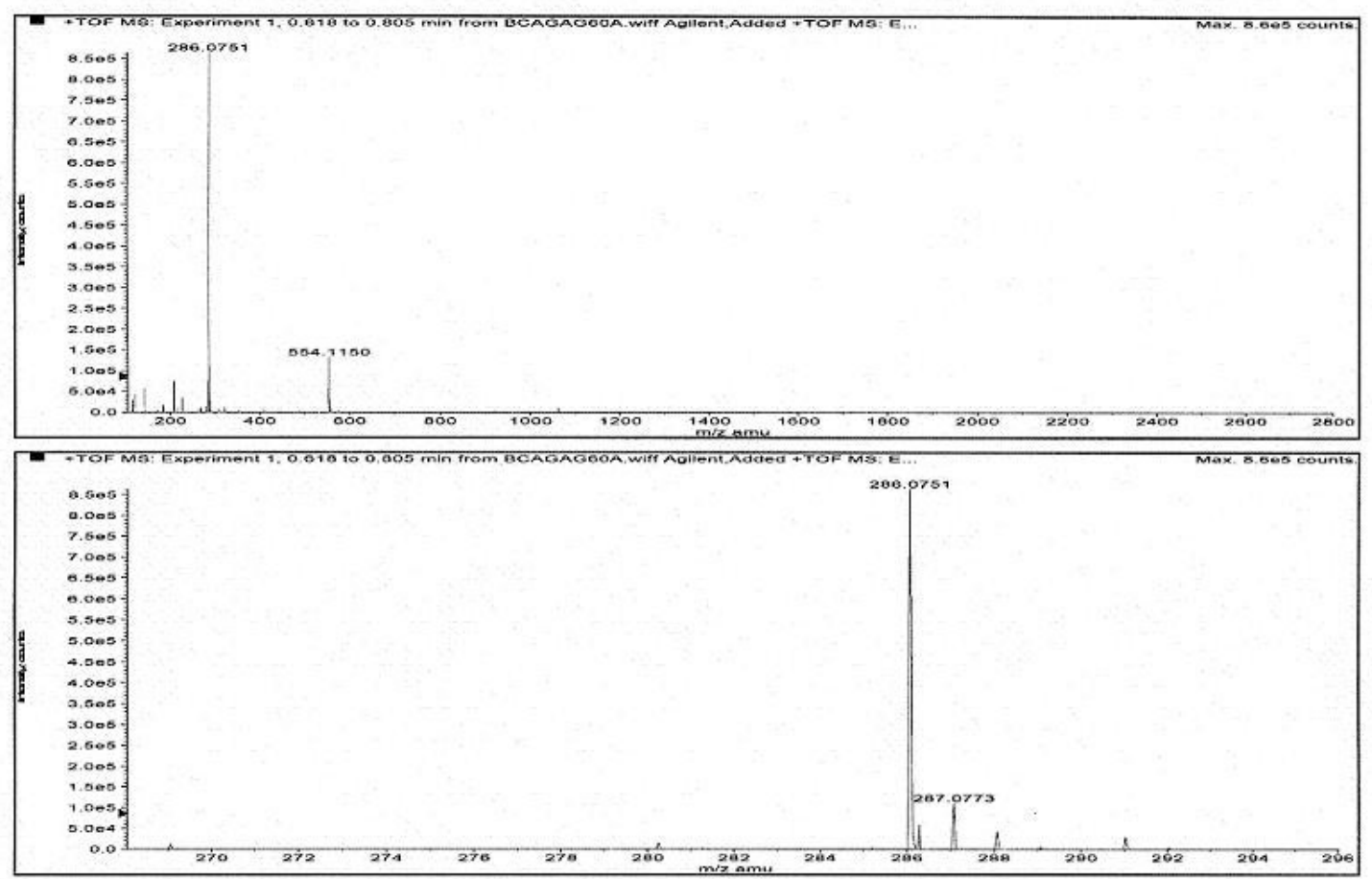

\begin{tabular}{|c|l|c|r|c|l|}
\hline Formula & Compound name & Mass & Peak RT (min) & Peak area & Description \\
\hline C12H12O5S1 & - & 268.04054 & 0.59 & $1.91161 \mathrm{E7}$ & - \\
\hline
\end{tabular}

\begin{tabular}{|l|r|r|r|r|r|r|}
\hline Species & Abundance (counts) & Ion Mass & Measured Mass & Error (mDa) & Error $(\mathrm{ppm})$ & Ret. Time Error (min) \\
\hline$[\mathrm{M}+\mathrm{H}]^{+}$ & 11805.93 & 269.04782 & 269.04757 & -0.25124 & -0.93 & - \\
\hline$[\mathrm{M}+\mathrm{NH} 4]^{+}$ & 865896.91 & 286.07437 & 286.07514 & 0.77348 & 2.70 & - \\
\hline$[\mathrm{M}+\mathrm{Na}]^{+}$ & 31548.26 & 291.02977 & 291.02974 & -0.02675 & -0.09 & - \\
\hline
\end{tabular}


Figure 13. ${ }^{1} \mathrm{H}$ NMR of 4-Mercaptocatechol, 6.

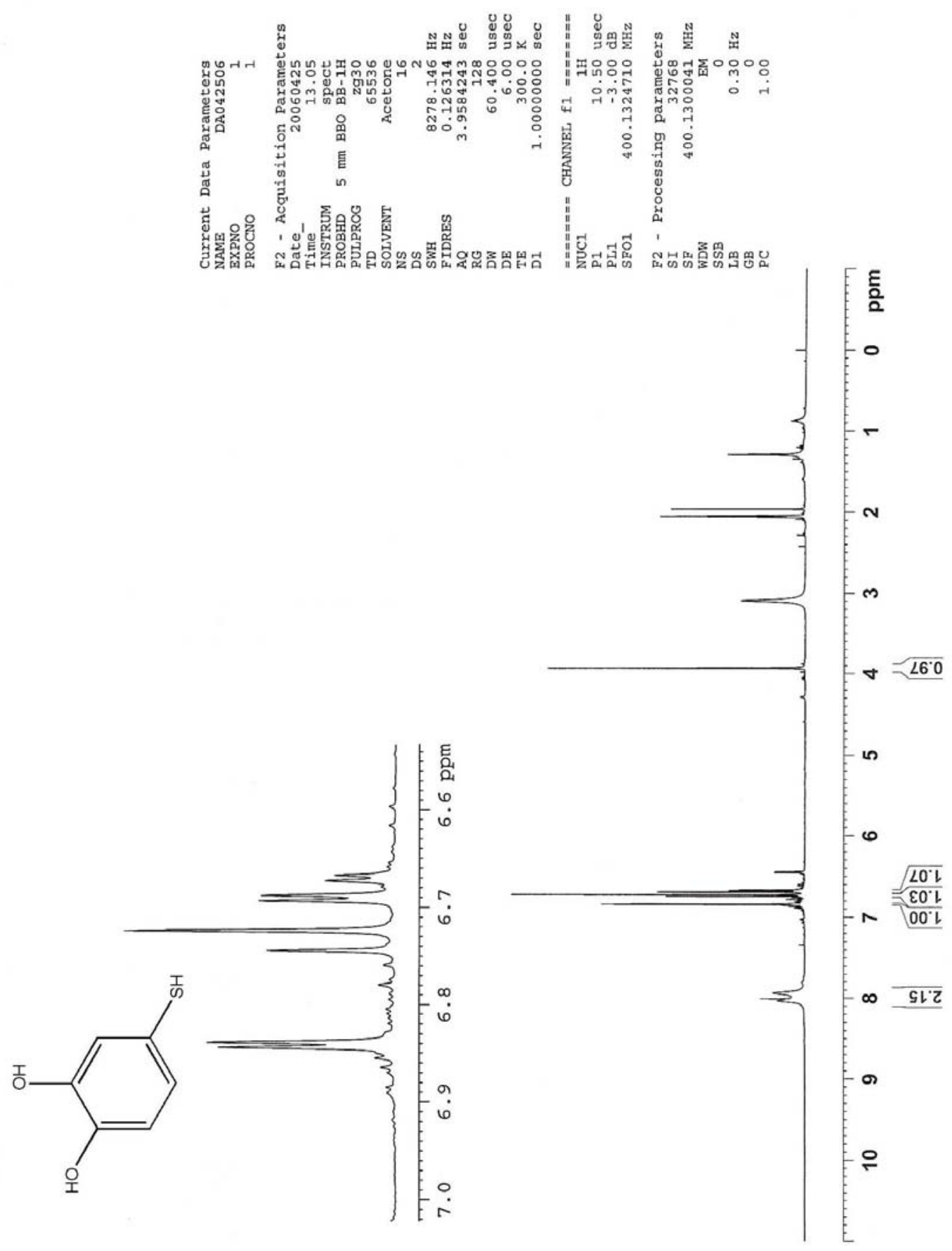


Figure 14. ${ }^{1} \mathrm{H}$ NMR of acetic acid 2-acetoxy-4-acetylsulfanyl-phenyl ester or "triacetylated 6" in acetone- $d_{6}$.

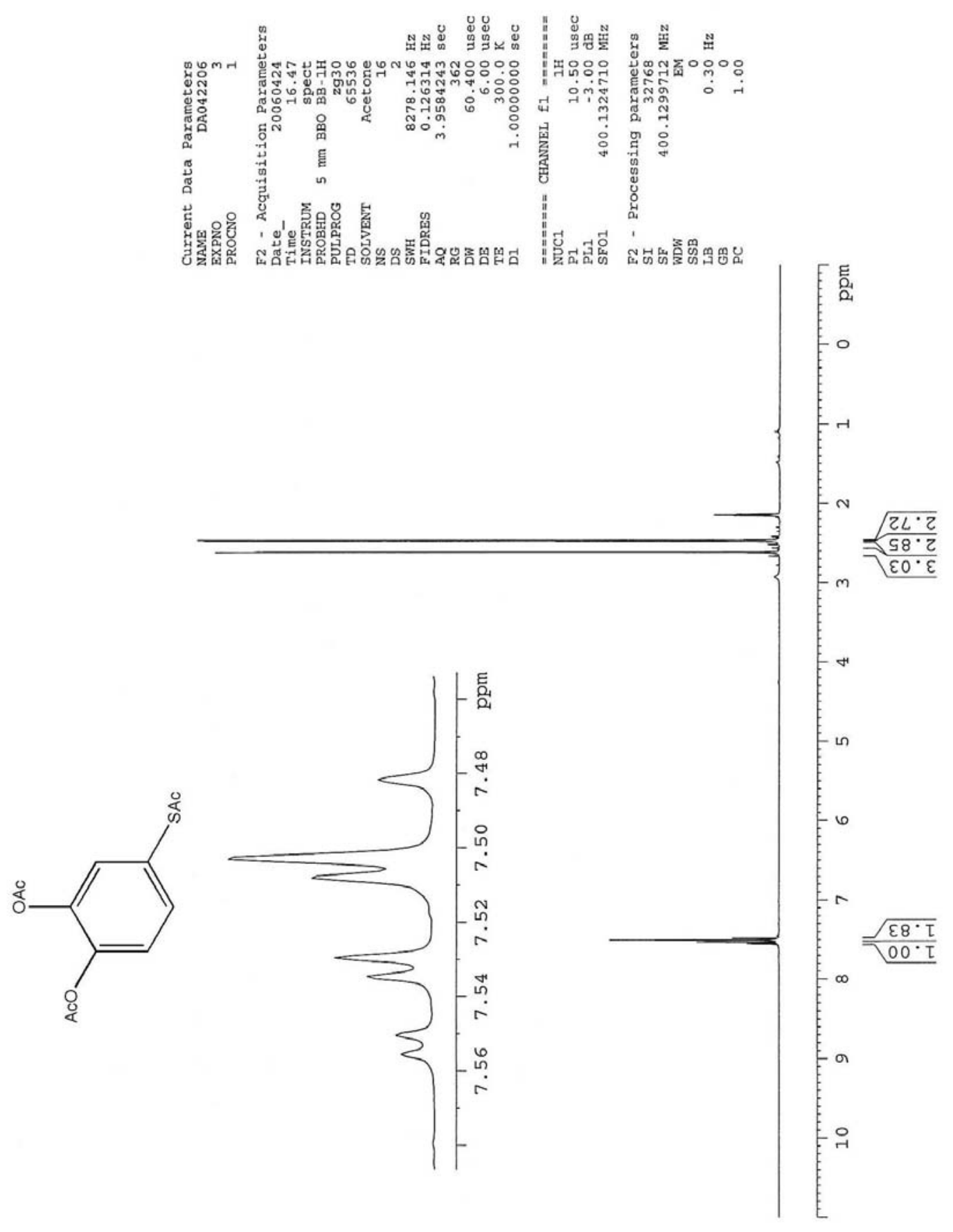


Figure 15. ${ }^{13} \mathrm{C}$ NMR of acetic acid 2-acetoxy-4-acetylsulfanyl-phenyl ester or "triacetylated 6 " in acetone- $d_{6}$.

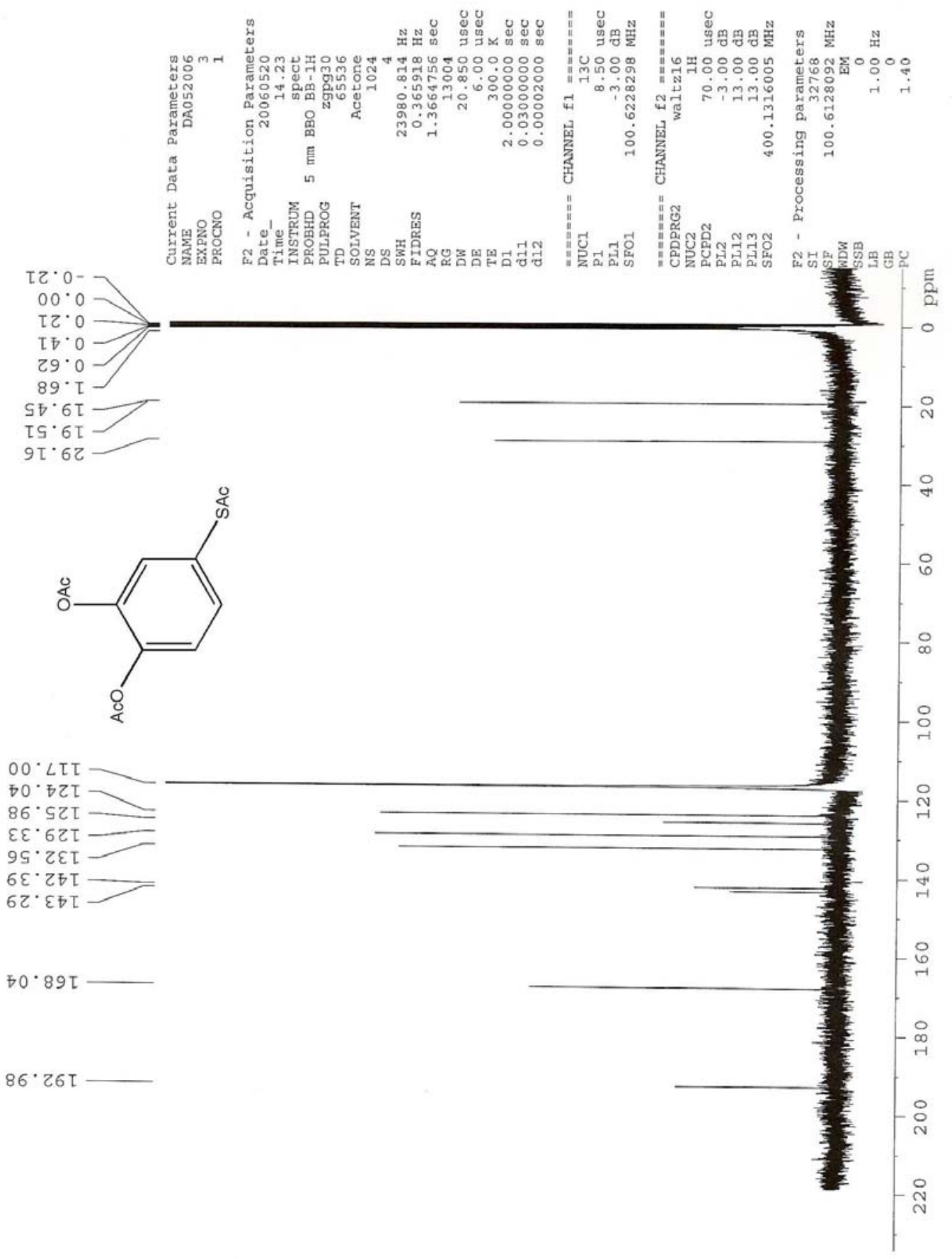


Figure 16. Mass spectrum of acetic acid 2-acetoxy-3acetylsulfanyl-phenyl ester or "triacetylated 6."

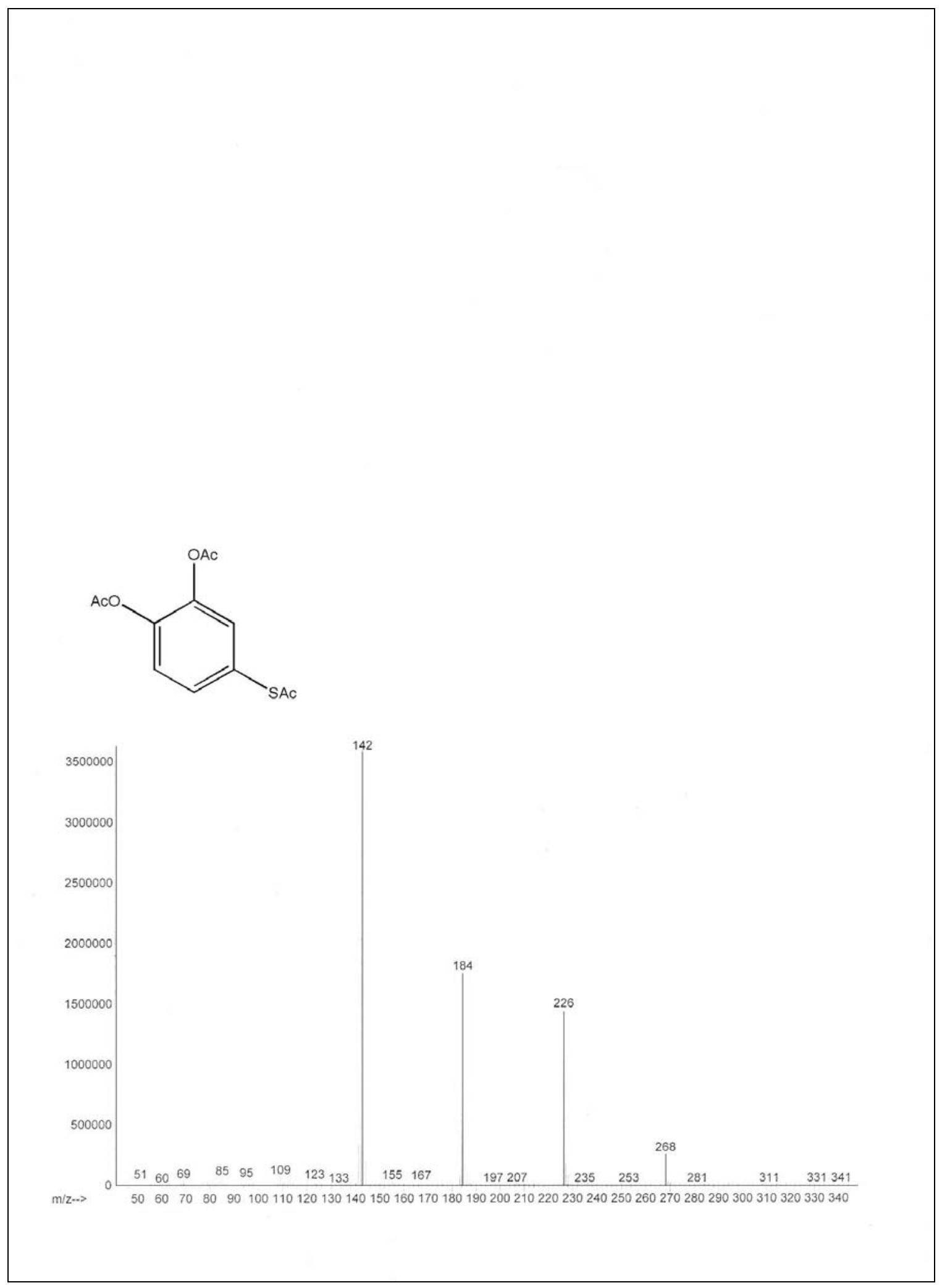


Figure 17. HRMS of acetic acid 2-acetoxy-3-acetylsulfanyl-phenyl ester or "triacetylated 6."

Empirical Formula Confirmation Report

Sample Name: 4-mercaptocatechol Sample Location: P1-A1 Sample Id: Operator:

Data File Name: D:IDatal0608281BCAGAG61A.wiff Acq Time: August 28 2006. 01:13:51 PM

Method: D:ITOF_DataldamethodslefcHC4.anmlefc.xmI

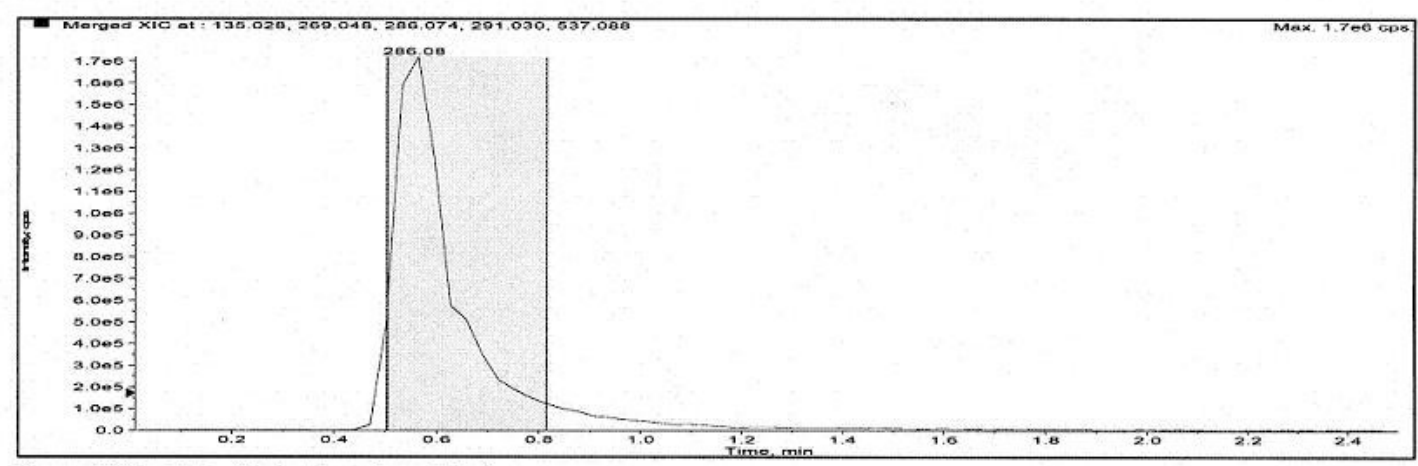

Merged XIC, Period\# : 1 Experiment\# : 1
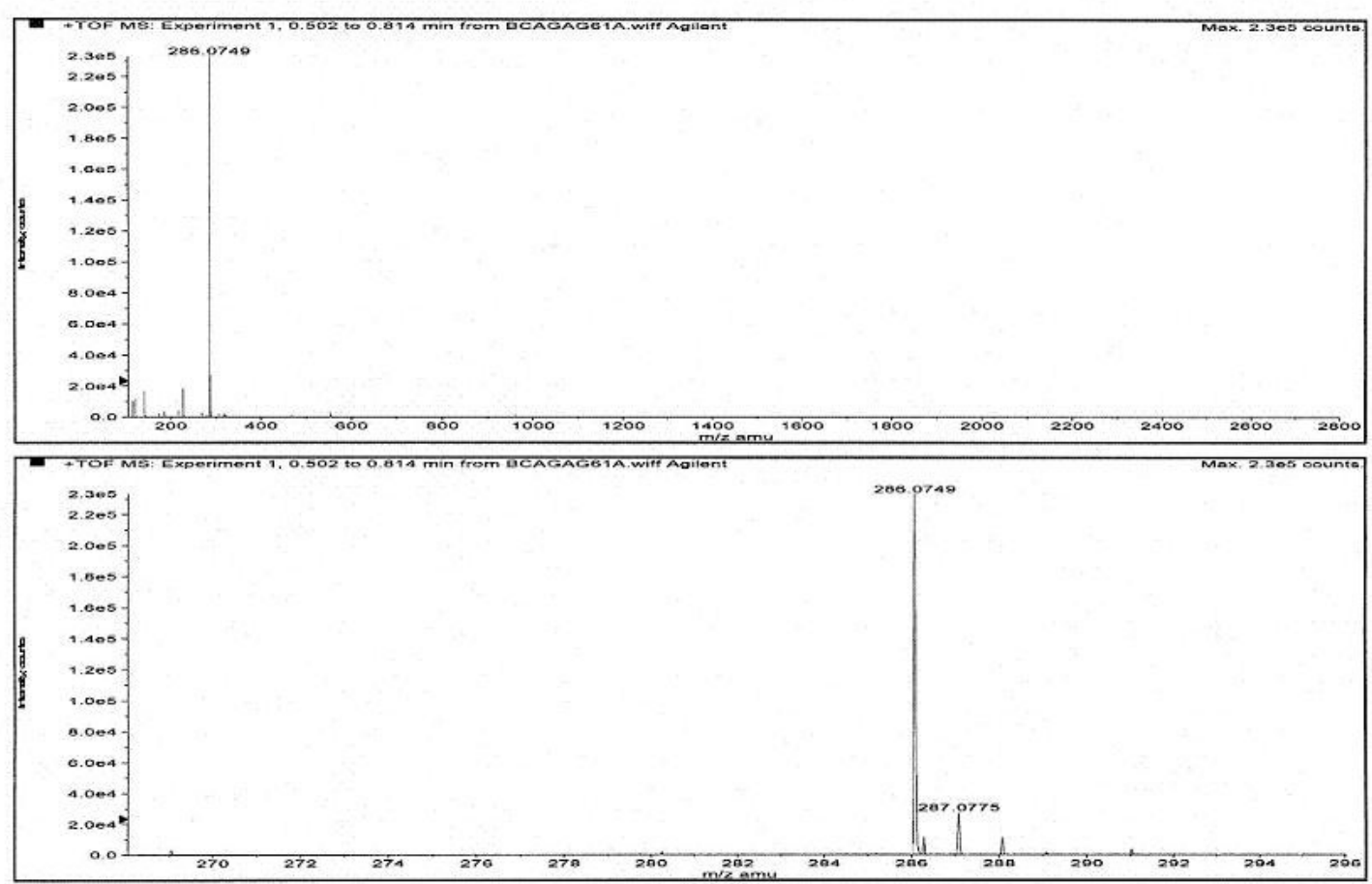

\begin{tabular}{|l|l|l|l|l|l|}
\hline Formula & Compound name & Mass & Peak RT (min) & Peak area & Description \\
\hline
\end{tabular}

\begin{tabular}{|l|l|r|r|r|l}
\hline $\mathrm{C} 12 \mathrm{H} 12 \mathrm{OSS1}$ & -- & 268.04054 & 0.56 & $1.40317 \mathrm{E7}$ & - \\
\hline
\end{tabular}

\begin{tabular}{|l|r|r|r|r|r|r|}
\hline Species & Abundance (counts) & Ion Mass & Measured Mass & Error (mDa) & Error (ppm) & Ret. Time Error (min) \\
\hline$[\mathrm{M}+\mathrm{H}]^{+}$ & 2918.42 & 269.04782 & 269.04778 & -0.04426 & -0.16 & - \\
\hline$[\mathrm{M}+\mathrm{NH} 4]^{+}$ & 235211.82 & 286.07437 & 286.07491 & 0.53848 & 1.88 & - \\
\hline$[\mathrm{M}+\mathrm{Na}]^{+}$ & 3593.43 & 291.02977 & 291.03020 & 0.43530 & 1.50 & - \\
\hline
\end{tabular}


Figure 18. ${ }^{1} \mathrm{H}$ NMR of acetic acid 2-acetoxy-6-(2,3-diacetoxyphenylsulfanyl)-phenyl ester or "tetraacetylated 7" in $\mathrm{CDCl}_{3}$.

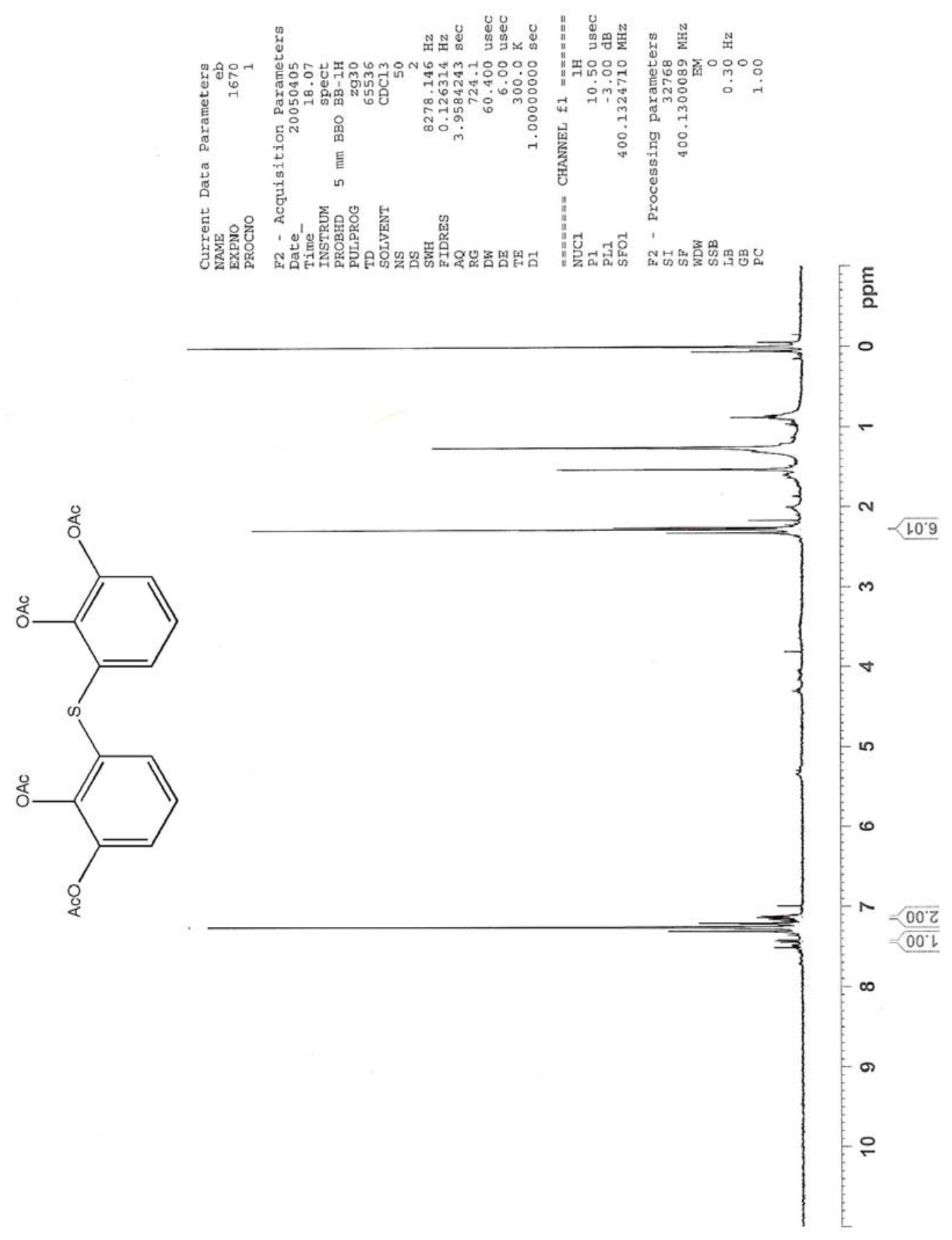


Figure 19. Mass spectrum of acetic acid 2-acetoxy-6-(2,3-diacetoxyphenylsulfanyl)-phenyl ester or "tetraacetylated 7."

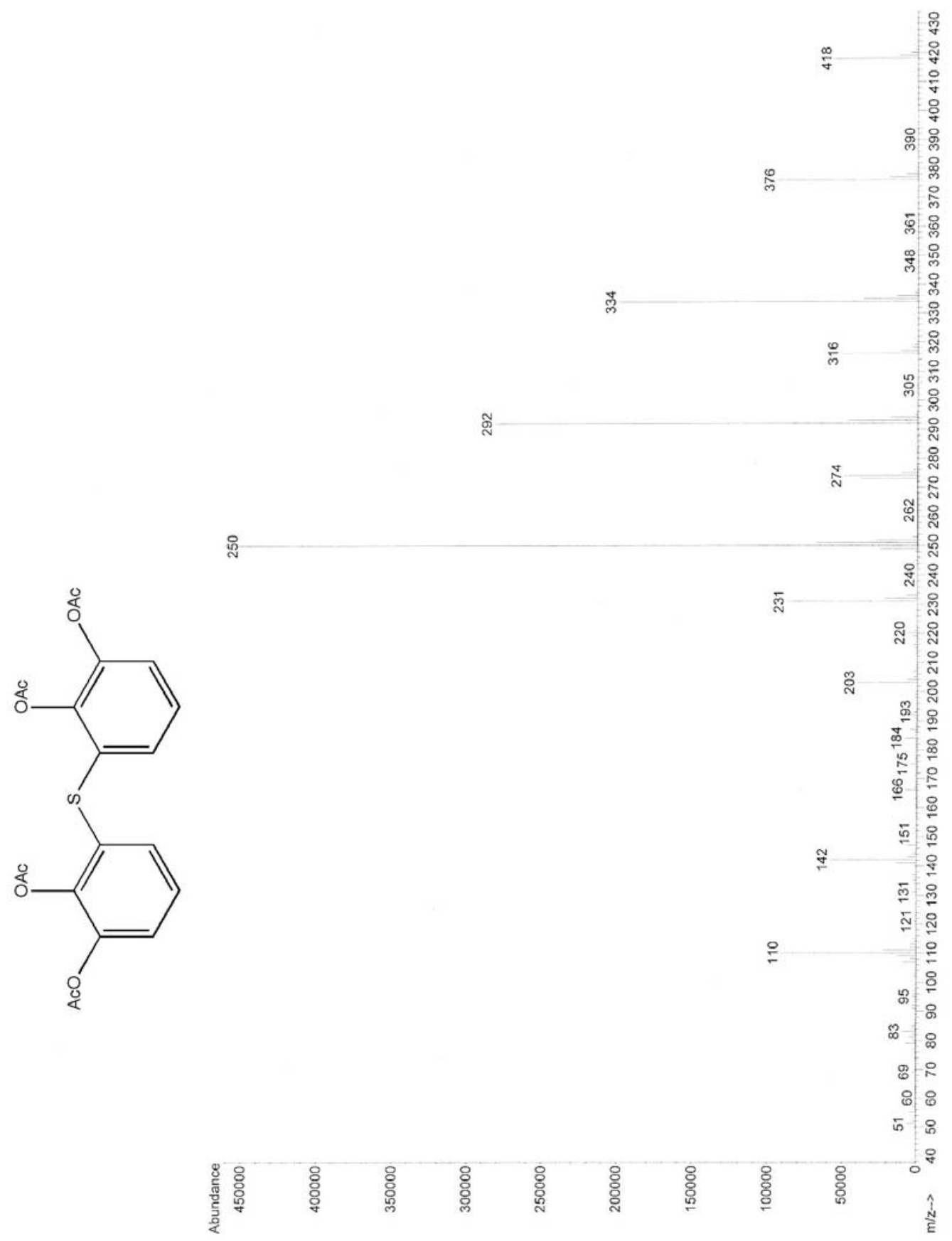


Figure 20. ${ }^{1} \mathrm{H}$ NMR of acetic acid 2-acetoxy-3-(2,3-diacetoxyphenyldisulfanyl)-phenyl ester or "tetraacetylated 8 " in acetone- $d_{6}$.

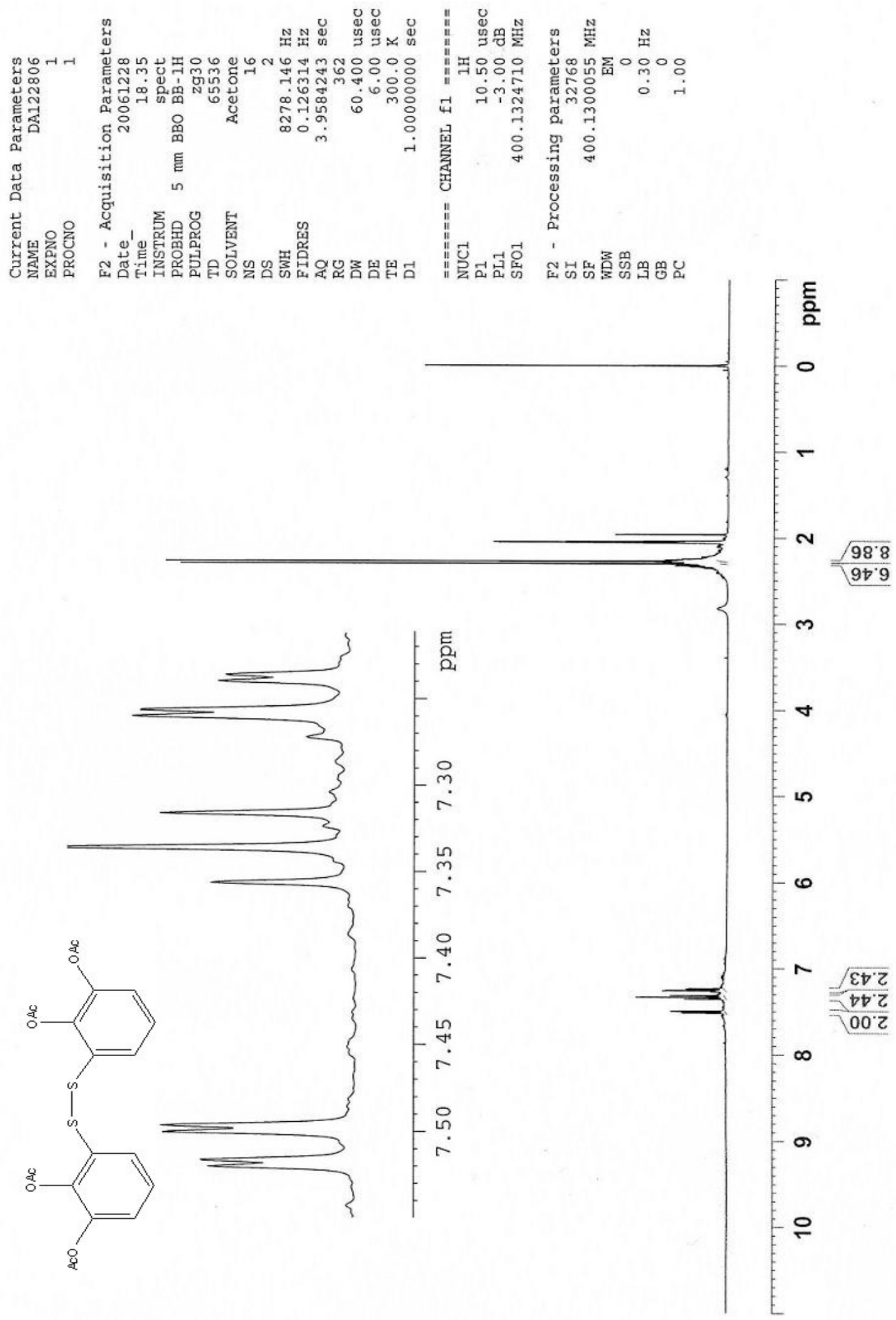


Figure 21. ${ }^{13} \mathrm{C}$ NMR of acetic acid 2-acetoxy-3-(2,3-diacetoxyphenyldisulfanyl)-phenyl ester or "tetraacetylated 8 " in acetone- $d_{6}$.

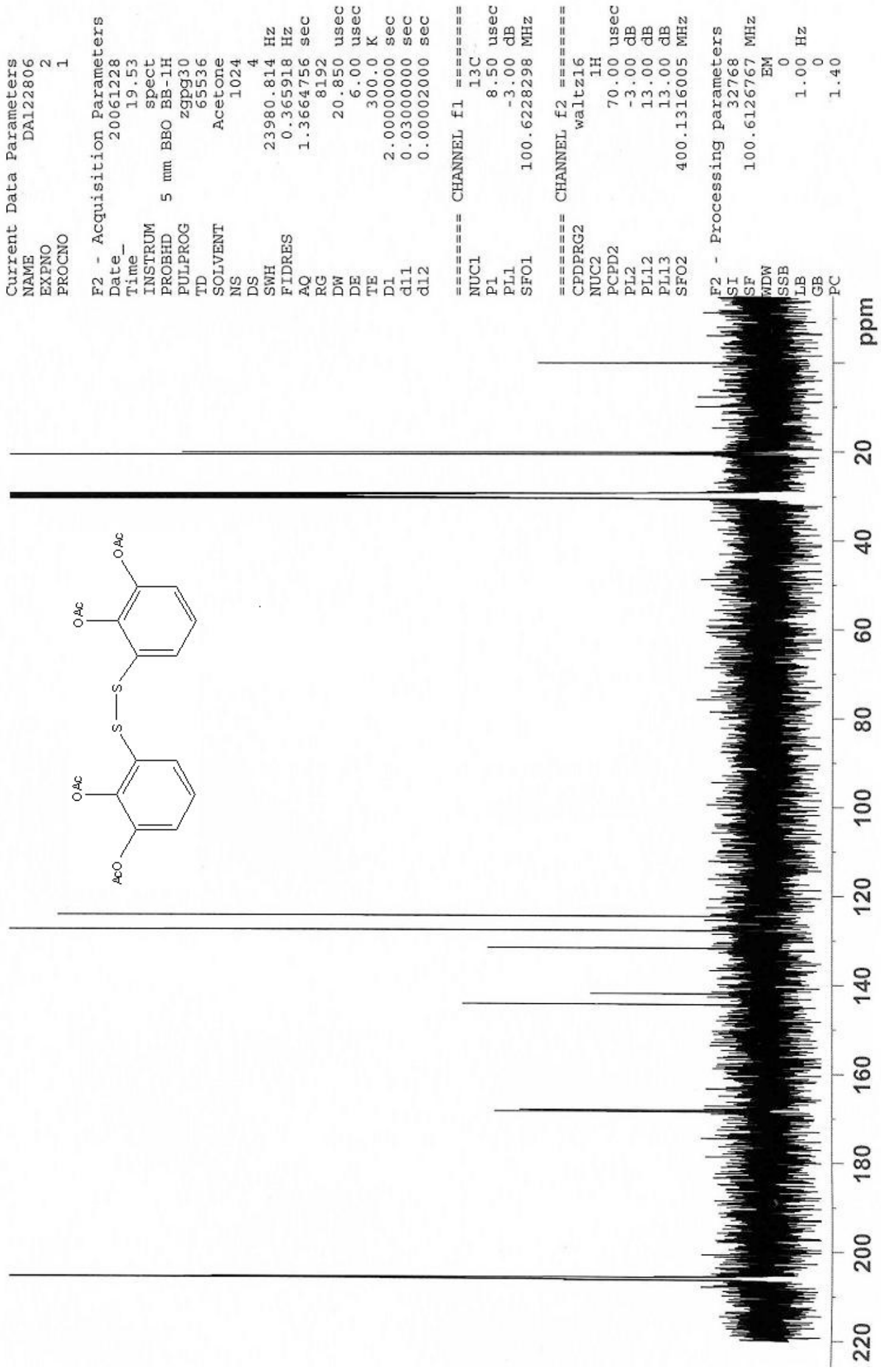


Figure 22. Mass spectrum of acetic acid 2-acetoxy-3-(2,3-diacetoxyphenyldisulfanyl)-phenyl ester or "tetraacetylated 8."

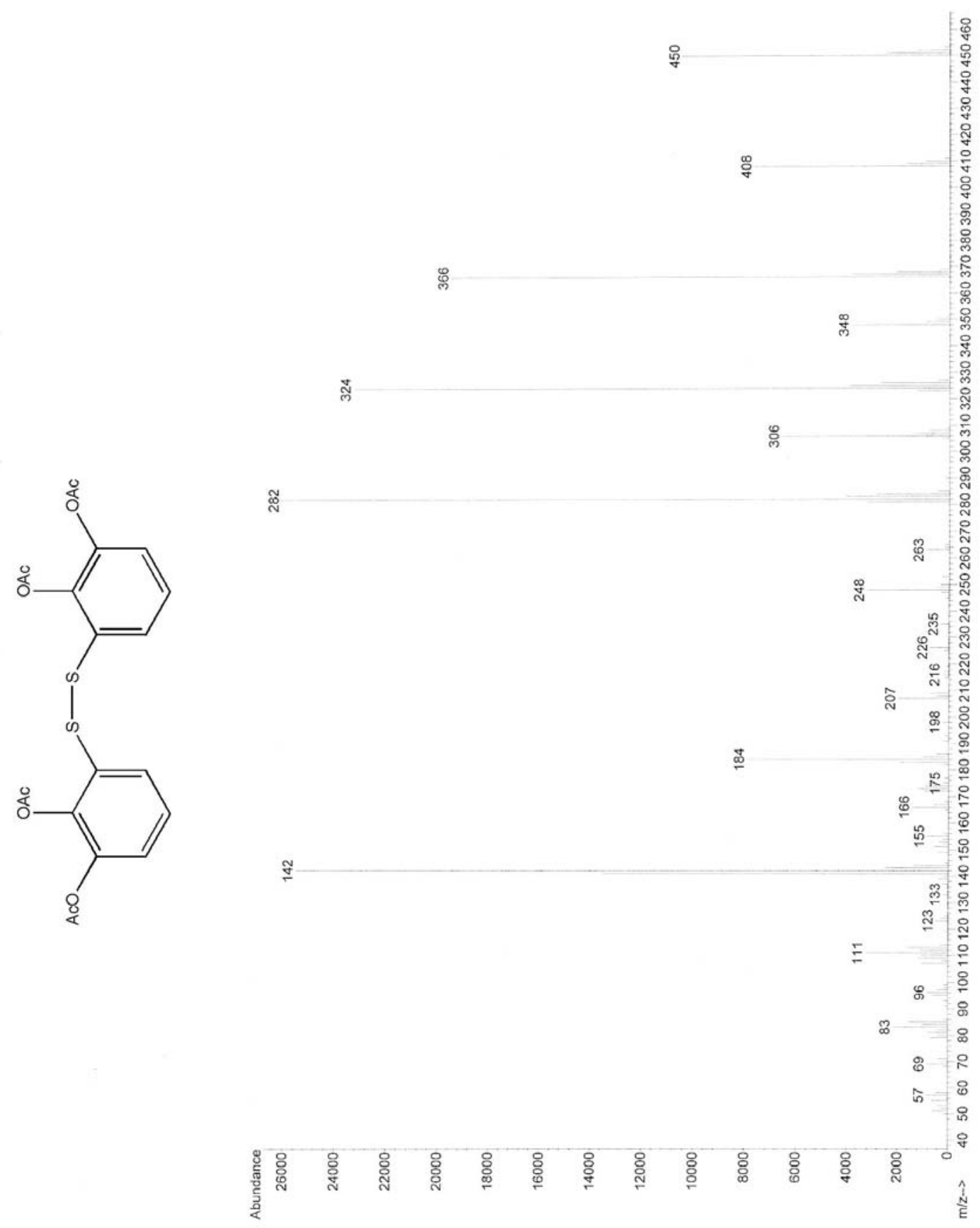


Figure 23. HRMS of acetic acid 2-acetoxy-3-(2,3-diacetoxy-phenyldisulfanyl)phenyl ester or "tetraacetylated 8."

Empirical Formula Confirmation Report

Sample Name: diphenyl disulfide Sample Location: P1-A1 Sample Id: Operator:

Data File Name: D:IDatal060828IBCAGAG62A.wiff Acq Time: August 28 2006, 01:23:45 PM

Method: D:ITOF_DataldamethodslefcHC4.anmlefc.xmI

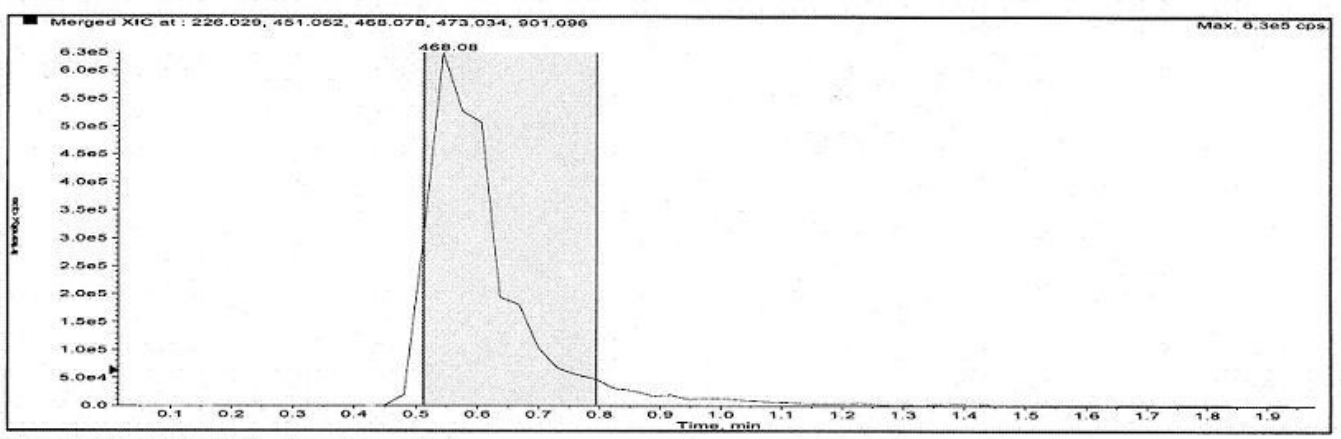

Merged XIC, Period\# : 1 Experiment\# : 1
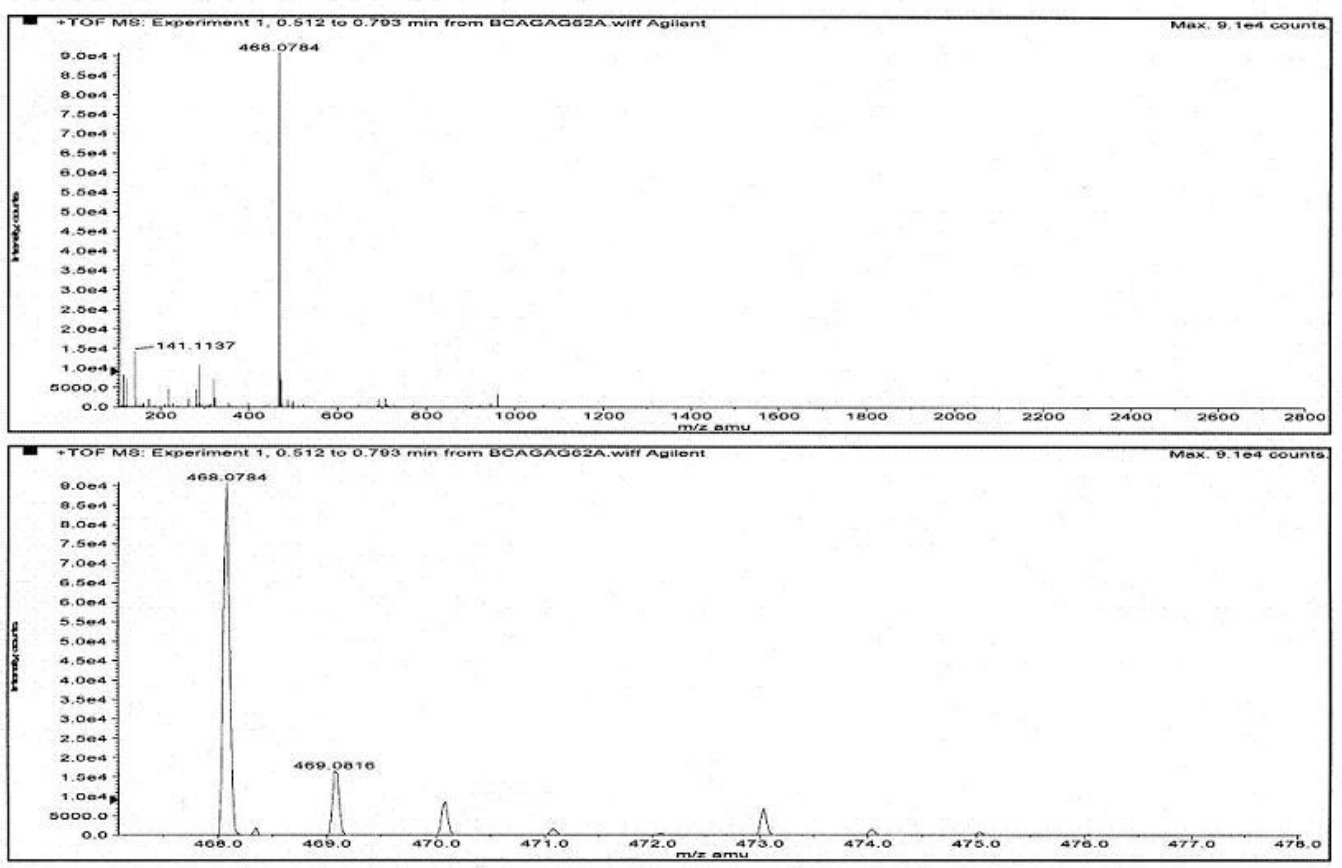

\begin{tabular}{|l|l|l|l|l|l|}
\hline Formula & Compound name & Mass & Peak RT $(\min )$ & Peak area & Description \\
\hline
\end{tabular}

\begin{tabular}{|l|l|l|r|r|r}
\hline $\mathrm{C} 20 \mathrm{H} 1808 \mathrm{~S} 2$ & -- & 450.04431 & 0.55 & $5.02142 \mathrm{E} 6$ & - \\
\hline
\end{tabular}

\begin{tabular}{|l|r|r|r|r|r|r|}
\hline \multicolumn{1}{|c|}{ Species } & Abundance (counts) & Ton Mass & Measured Mass & Error (mDa) & Error (ppm) & Ret. Time Error (min) \\
\hline$[\mathrm{M}+\mathrm{NH4}]^{+}$ & 91166.19 & +68.07813 & 7468.07843 & 0.29991 & 0.64 & - \\
\hline$[\mathrm{M}+\mathrm{Na}]^{+}$ & 6999.85 & 473.03353 & 473.03405 & 0.51776 & 1.09 & - \\
\hline & & & &
\end{tabular}


Figure 24. ${ }^{1} \mathrm{H}$ NMR for 3,4-dimercapto-benzene-1,2-diol or "tetraacetylated 9."

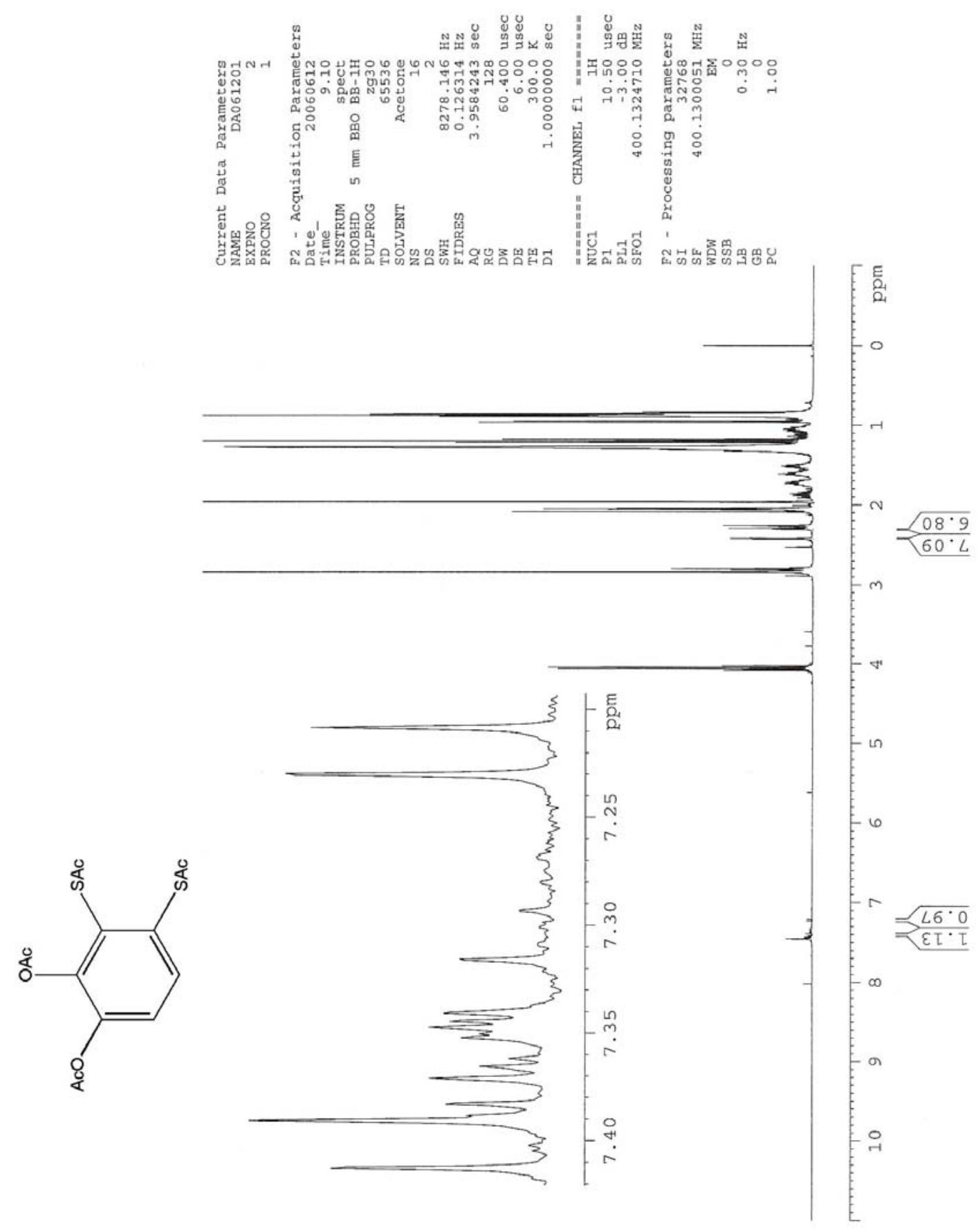


Figure 25. Mass spectrum of 3,4-dimercapto-benzene-1,2-diol or "tetraacetylated 9."

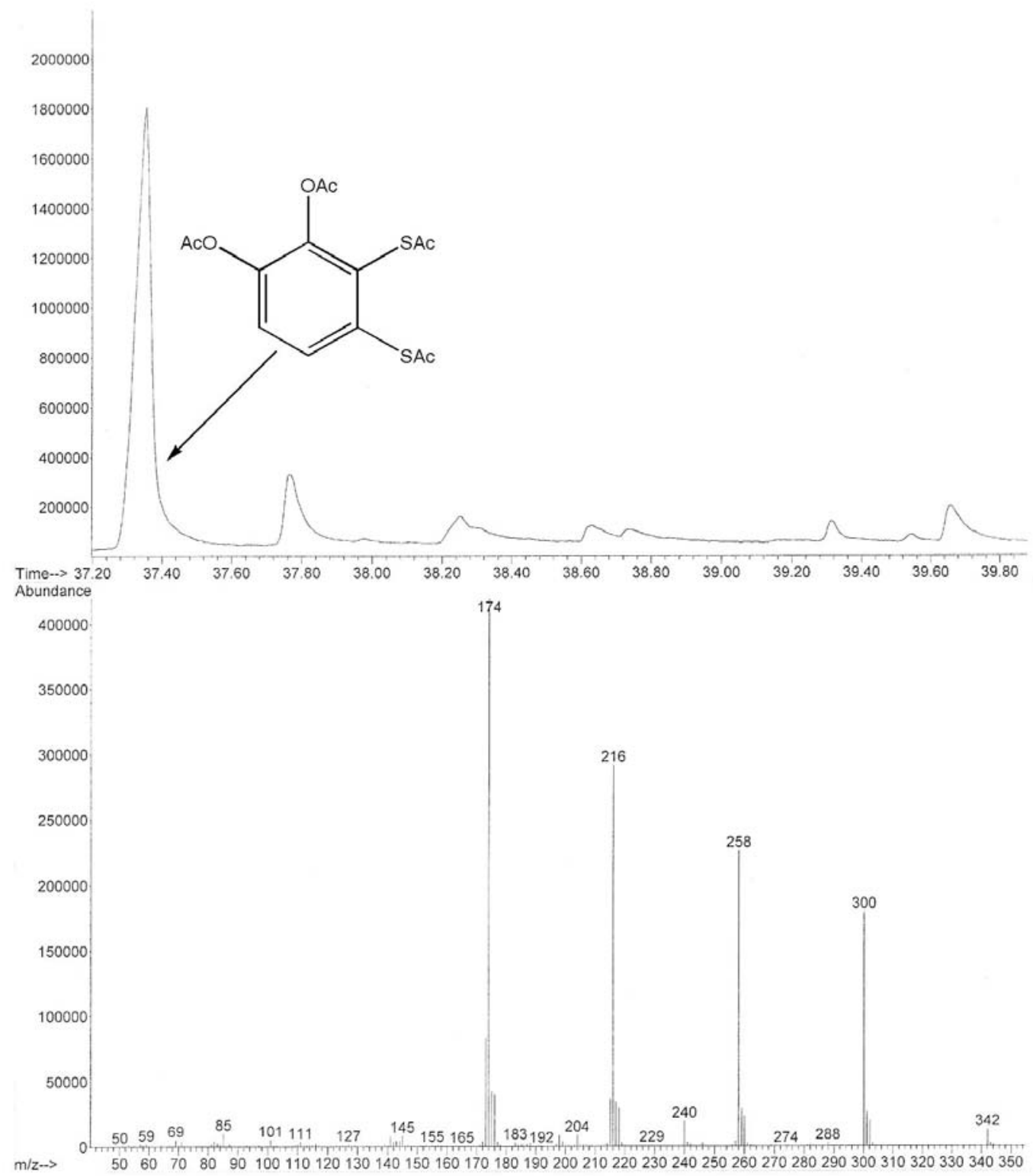


Figure 26. Mass spectrum of acetic acid 3,2',3'-triacetoxy-biphenyl-2-yl ester or "tetraacetylated 10."

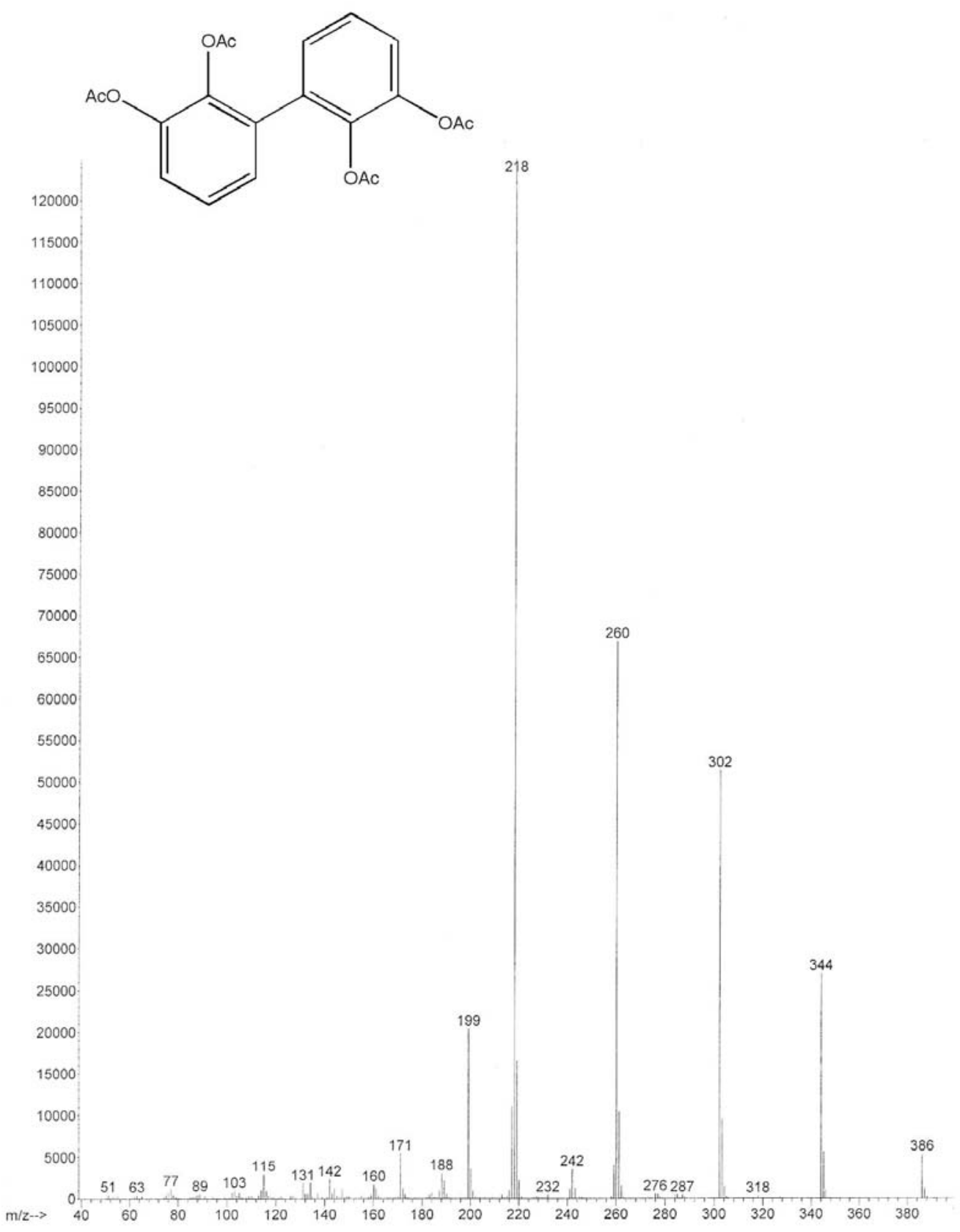


Figure 27. Mass spectrum of acetic acid 2-(3,4-diacetoxy-phenoxy)-phenyl ester or "triacetylated 11."

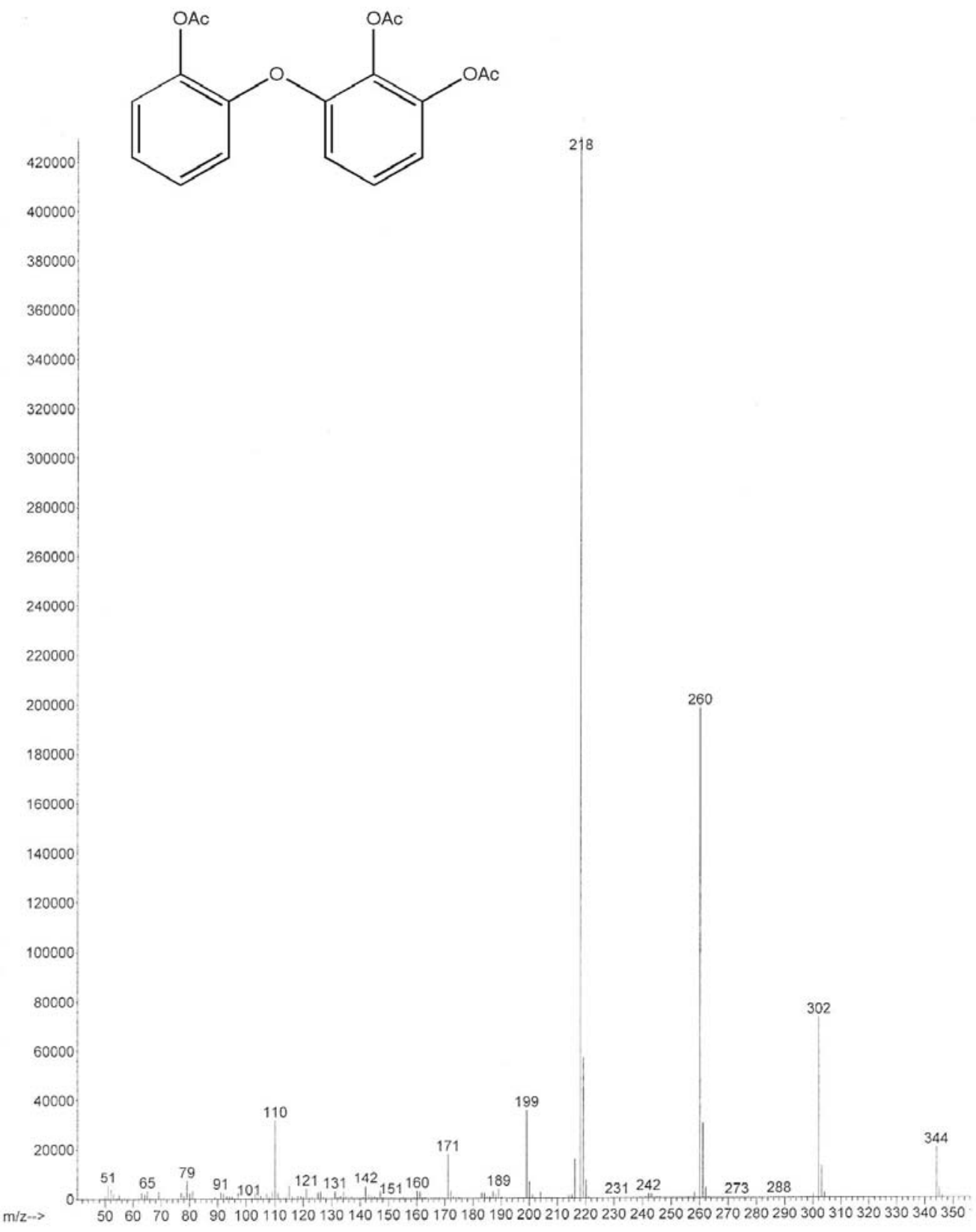


Figure 28. Mass spectrum of acetic acid 1-acetoxy-dibenzo[1,4]dioxin-2-yl ester or "diacetylated 12."

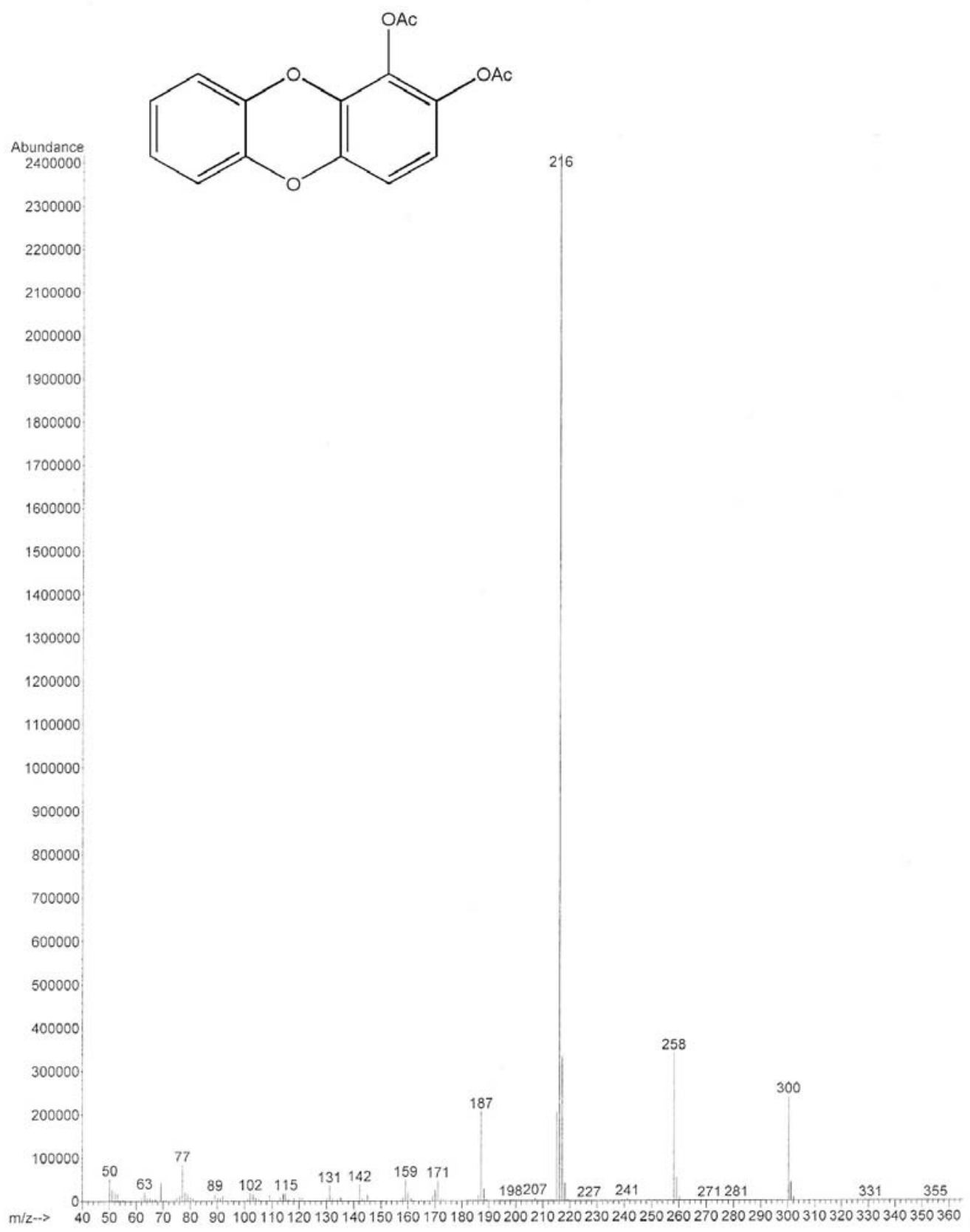


Figure 29. ${ }^{1} \mathrm{H}$ NMR of $o$-benzoquinone in acetone- $d_{6}$.

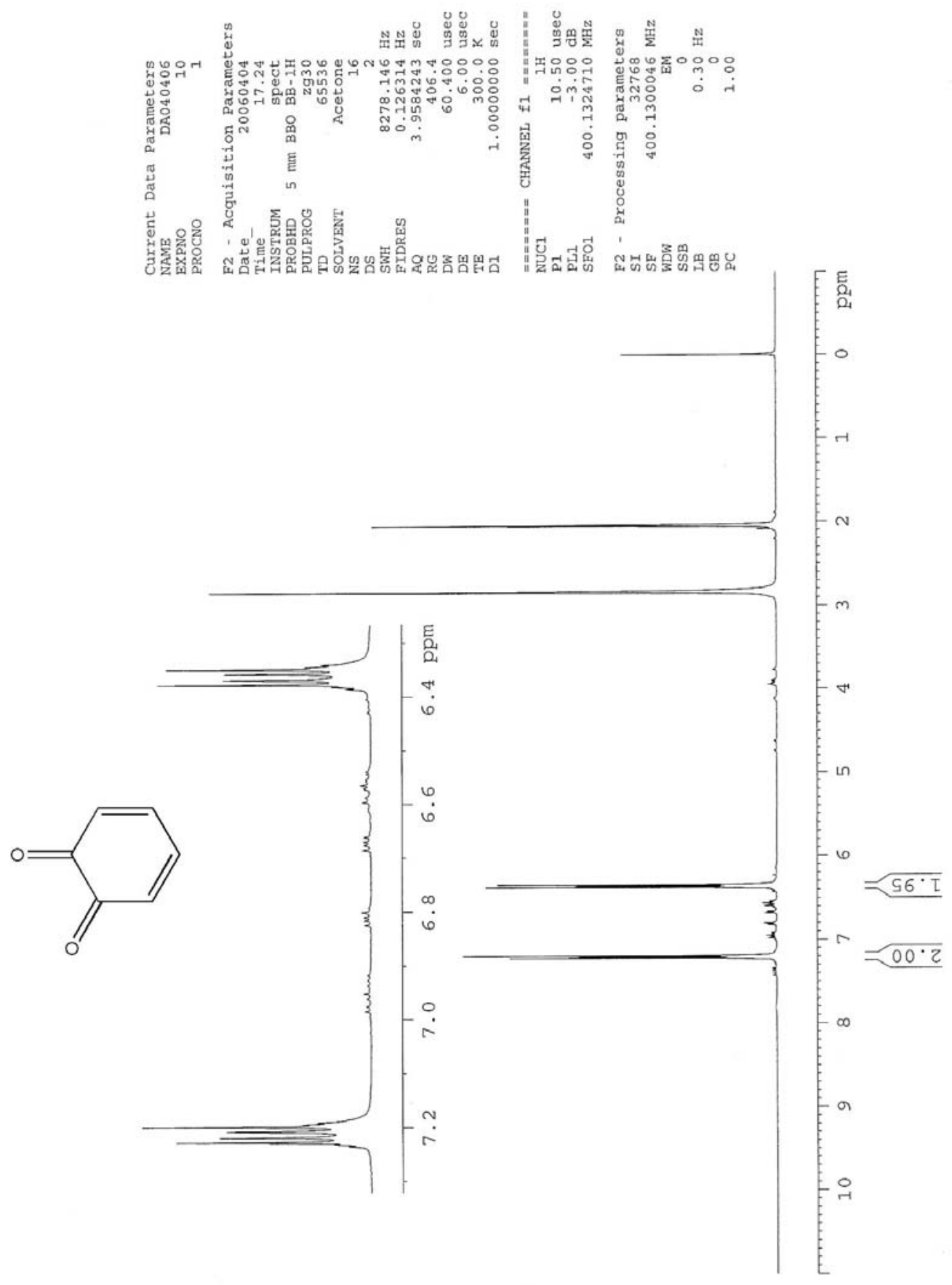


Description of the geometry of the stationary point of $\mathbf{5}(\mathrm{x}=8)$ (cartesian coordinates) and absolute energy in hartrees. B3LYP/6-31G* gas phase $($ Charge $=0$, spin state $=1)$ 3568.2238471

01

$\begin{array}{lrrr}\text { C } & -3.39555400 & 0.82480700 & 0.17681900 \\ \mathrm{C} & -3.32644900 & -0.31321100 & -0.63816200 \\ \mathrm{C} & -4.14610500 & -1.41933500 & -0.34260600 \\ \mathrm{C} & -5.01968800 & -1.38892600 & 0.73621500 \\ \mathrm{C} & -5.08879300 & -0.24773100 & 1.54456500 \\ \mathrm{C} & -4.28172300 & 0.84917200 & 1.26779600 \\ \mathrm{H} & -5.77223300 & -0.22596200 & 2.38743800 \\ \mathrm{H} & -5.64538600 & -2.25382800 & 0.94752600 \\ \mathrm{O} & -2.47936700 & -0.36315100 & -1.69562900 \\ \mathrm{H} & -2.57560000 & -1.23934400 & -2.10939900 \\ \mathrm{O} & -3.99590800 & -2.48163500 & -1.20402200 \\ \mathrm{H} & -4.56937400 & -3.21364600 & -0.93179400 \\ \mathrm{~S} & -2.43618300 & 2.27878300 & -0.21816100 \\ \mathrm{~S} & -0.56963200 & 1.97431400 & 0.70223100 \\ \mathrm{~S} & 0.77058700 & 1.16843200 & -0.70379000 \\ \mathrm{~S} & 0.67580800 & -0.93432700 & -0.64567300 \\ \mathrm{~S} & 1.88393700 & -1.62200500 & 0.92683800 \\ \mathrm{~S} & 3.86265100 & -1.81527500 & 0.23167100 \\ \mathrm{~S} & 4.90951000 & -0.08393800 & 0.79415000 \\ \mathrm{~S} & 4.81528500 & 1.29792000 & -0.77562700 \\ \mathrm{H} & -4.32483800 & 1.73857400 & 1.88748700 \\ \mathrm{H} & 3.64810100 & 1.90136800 & -0.43803700\end{array}$


Description of the geometry of the stationary point of $\mathbf{1 9}$ (cartesian coordinates) and absolute energy in hartrees. B3LYP/6-31G* gas phase $($ Charge $=0$, spin state $=1)$ 2372.4202041

01

$\begin{array}{llll}\text { C } & -0.91333597 & 0.97251739 & 1.64888051\end{array}$

$\begin{array}{llll}\text { C } & -0.35433597 & -0.27848261 & 2.01288051\end{array}$

$\begin{array}{llll}\mathrm{C} & 0.05366403 & -1.16148261 & 1.02088051\end{array}$

$\begin{array}{llll}\text { C } & -0.05733597 & -0.84748261 & -0.34511949\end{array}$

$\begin{array}{lllll}\text { C } & -0.62833597 & 0.38551739 & -0.71511949\end{array}$

$\begin{array}{lllll}\text { C } & & -1.08633597 & 1.28251739 & 0.29288051\end{array}$

$\begin{array}{llll}\mathrm{S} & -0.77233597 & 0.77751739 & -2.46111949\end{array}$

S $\quad 0.75166403 \quad 2.18651739 \quad-2.83111949$

S $\quad-0.16433597 \quad 4.06051739 \quad-2.54811949$

S $\quad-0.47033597 \quad 4.16851739 \quad-0.46211949$

$\begin{array}{lllll}\mathrm{S} & -1.88733597 & 2.84851739 & -0.07011949\end{array}$

$\begin{array}{llll}\mathrm{O} & -1.29433597 & 1.87351739 & 2.65288051\end{array}$

$\begin{array}{llll}\mathrm{O} & -0.27233597 & -0.52348261 & 3.38988051\end{array}$

$\begin{array}{llll}\mathrm{H} & 0.46366403 & -2.12748261 & 1.29188051\end{array}$

$\begin{array}{llll}\mathrm{H} & -1.12801495 & 1.45078479 & 3.47582307\end{array}$

$\mathrm{H} \quad \begin{array}{llll}0.29254027 & -1.57197382 & -1.05052654\end{array}$

$\mathrm{H} \quad-1.57557813 \quad-0.07416471 \quad-0.52452922$ 
Description of the geometry of the stationary point of $\mathrm{H}_{2} \mathrm{~S}_{3}$ (cartesian coordinates) and absolute energy in hartrees. B3LYP/6-31G* gas phase $($ Charge $=0$, spin state $=1)$ 1195.7664858

$\begin{array}{lccc}\mathrm{S} & -1.70392200 & -0.38318900 & -0.08585000 \\ \mathrm{H} & -1.88405200 & -0.58399200 & 1.24215100 \\ \mathrm{~S} & -0.00001600 & 0.83936400 & 0.00000300 \\ \mathrm{~S} & 1.70392000 & -0.38317900 & 0.08584200 \\ \mathrm{H} & 1.88434800 & -0.58394300 & -1.24207600\end{array}$

